\title{
Stereoselective $C$-Glycosylation Reactions of Pyranoses: The Conformational Preference and Reactions of the Mannosyl Cation
}

\author{
Claudia G. Lucero and K. A. Woerpel* \\ Department of Chemistry, University of California \\ Irvine, CA 92697-2025
}

\section{Supporting Information}

\section{Contents:}

I. Synthesis of the acetate substrates $\quad S-1$

$\begin{array}{ll}\text { II. Nucleophilic substitution of acetate substrates } & S-7\end{array}$

III. Stereochemical proofs of nucleophilic substituted products $S-9$

IV. Bibliography $\quad S-13$

$\begin{array}{ll}\text { V. Selected GCMS and }{ }^{1} \mathrm{H} \text { NMR spectra } & S-14\end{array}$

\section{General.}

${ }^{1} \mathrm{H}$ NMR and ${ }^{13} \mathrm{C}$ NMR spectra were recorded at ambient temperature at $500 \mathrm{MHz}$ and $125 \mathrm{MHz}$, respectively. All chemical shifts are reported in ppm relative to tetramethylsilane on the $\square$ scale, multiplicity $(\mathrm{br}=\mathrm{broad}, \mathrm{s}=$ singlet, $\mathrm{d}=$ doublet, $\mathrm{t}=$ triplet, $\mathrm{q}=$ quartet, quint = quintet, and $\mathrm{m}=$ multiplet), coupling constants in $\mathrm{Hz}$, and integration. Analytical gas-liquid chromatography (GC) analyses were performed on a chromatograph, equipped with a split-mode injection system and a flame ionization detector. Fused silica capillary column (30 $\mathrm{m} \square 0.32 \mathrm{~mm}$ ) wall coated with DB-1 was used with helium as the carrier gas (16 psi column head pressure). Liquid chromatography was performed using forced flow (flash chromatography) with the indicated solvent on $60 \AA$ silica gel $\left(\mathrm{SiO}_{2}\right)$. All reactions were performed under nitrogen atmosphere in flame-dried glassware using standard syringe/septa techniques. Unless otherwise stated, all reagents were used unpurified from the supplier. $\mathrm{CH}_{2} \mathrm{Cl}_{2}$ and THF were dried non-pyrophorically as in the method of Grubbs. ${ }^{1}$ All other solvents were dried and distilled. $\mathrm{NaH}$ was washed with hexanes and dried under reduced pressure. 


\section{Synthesis of the acetate substrates}

A. 5-Benzyloxymethyl Acetate 9.

Acetate 9 was prepared according to the following procedure:

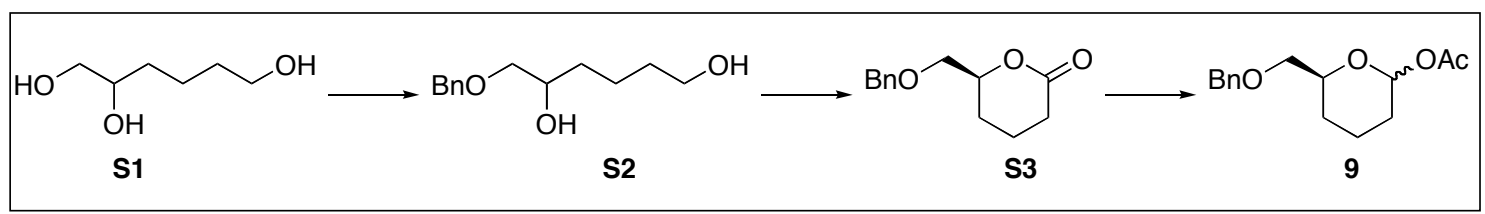

1-Benzyloxy-2,6-hexanediol (S2): ${ }^{2}$ A solution of 1,2,6-hexanetriol S1 (2.00 g, $14.9 \mathrm{mmol}$ ) and bis(tributyltin) oxide $(4.70 \mathrm{~mL}, 6.80 \mathrm{mmol})$ in toluene $(24 \mathrm{~mL})$ was heated to $90{ }^{\circ} \mathrm{C}$ for $8 \mathrm{~h}$ employing a Dean Stark trap. The reaction mixture was cooled to $23{ }^{\circ} \mathrm{C}$ and benzyl bromide $(7.20 \mathrm{~mL}, 60.4 \mathrm{mmol})$ and tetrabutylammonium bromide $(3.40 \mathrm{~g}, 10.4 \mathrm{mmol})$ were added. The solution was heated to $90{ }^{\circ} \mathrm{C}$ for $5 \mathrm{~h}$. The reaction mixture was cooled to $23{ }^{\circ} \mathrm{C}$, diluted with $\mathrm{CH}_{2} \mathrm{Cl}_{2}(100 \mathrm{~mL})$, and washed with saturated aqueous $\mathrm{NaHCO}_{3}(45 \mathrm{~mL})$. The phases were separated and the aqueous phase was extracted with $\mathrm{CH}_{2} \mathrm{Cl}_{2}(3 \square 90 \mathrm{~mL})$. The combined organic extracts were washed with brine $(45 \mathrm{~mL})$, filtered through $\mathrm{Na}_{2} \mathrm{SO}_{4}$, and concentrated in vacuo. The resulting oil was purified by flash column chromatography (hexanes to 1:4 EtOAc/hexanes) to afford the product ${ }^{2}$ as a colorless oil (2.14 g, 63\%): ${ }^{1} \mathrm{H}$ NMR $\left(500 \mathrm{MHz} \mathrm{CDCl}_{3}\right) \square 7.36-7.26(\mathrm{~m}, 5 \mathrm{H}), 4.58-4.49(\mathrm{~m}, 2 \mathrm{H}), 3.80(\mathrm{~m}$, $1 \mathrm{H}), 3.59(\mathrm{~m}, 2 \mathrm{H}), 3.47(\mathrm{dd}, J=9.5,3.2,1 \mathrm{H}), 3.34-3.31(\mathrm{dd}, J=9.4,7.8,1 \mathrm{H}), 2.86(\mathrm{bs}, 1 \mathrm{H}), 2.31(\mathrm{bs}, 1 \mathrm{H})$, 1.57-1.38 (m, 6H); ${ }^{13} \mathrm{C}$ NMR (125 MHz, $\left.\mathrm{CDCl}_{3}\right) \square 138.4,128.9,128.24,128.21,75.1,73.8,70.7,62.9,33.1$, 32.9, 22.1; IR (thin film) 3350, 2937, 2863, 1454, $1099 \mathrm{~cm}^{-1}$; HRMS (EI/GCMS) $m / z$ calcd for $\mathrm{C}_{13} \mathrm{H}_{20} \mathrm{NaO}_{3}(\mathrm{M}$ $+\mathrm{Na})^{+}$247.1310, found 247.1304.

6-Benzyloxymethyltetrahydropyran-2-one (S3): A solution of $\mathbf{S 2}(0.400 \mathrm{~g}, 1.78 \mathrm{mmol})$ and PDC (1.00 g, $2.70 \mathrm{mmol}$ ) in $\mathrm{CH}_{2} \mathrm{Cl}_{2}$ was transferred by cannula into a flask containing flame-dried $4-\AA$ molecular sieves. Sodium acetate $(0.073 \mathrm{~g}, 0.89 \mathrm{mmol})$ was added and the reaction mixture was stirred for $24 \mathrm{~h}^{2}{ }^{2}$ The mixture was adsorbed onto silica gel $(20 \mathrm{~mL})$ and purified by flash column chromatography to afford the product ${ }^{3}$ as a colorless oil $(0.230 \mathrm{~g}, 58 \%)$. Although the literature procedure ${ }^{2}$ indicated that the hemiacetal should be the major product, we obtained the lactone; a chromium-based oxidation of a related diol also provided the lactone: ${ }^{4}$ ${ }^{1} \mathrm{H}$ NMR (500 MHz, $\mathrm{CDCl}_{3}$ ) 口7.37-7.27 (m, 5H), 4.58 (bs, 2H), 4.50-4.47 (m, 1H), 3.66-3.59 (m, 2H), 2.62-2.56 (m, 1H), 2.49-2.43 (m, 1H), 1.97-1.92(m, 2H), 1.86-1.82 (m, 1H), 1.75-1.71 (m, 1H); ${ }^{13} \mathrm{C}$ NMR $\left(125 \mathrm{MHz}, \mathrm{CDCl}_{3}\right) \square 171.4,138.1,128.7,128.0,127.9,79.4,73.8,72.1,29.9,24.9$, 18.5; IR (thin film) 2951, 2868, 1735, 1241, $1067 \mathrm{~cm}^{-1}$; HRMS (EI/GCMS) $m / z$ calcd for $\mathrm{C}_{13} \mathrm{H}_{16} \mathrm{NaO}_{3}(\mathrm{M}+\mathrm{Na})^{+} 243.0997$, found 243.0999.

2-Acetoxy-6-benzyloxymethylterahydropyran (9): A solution of $\mathbf{S 3}(0.150 \mathrm{~g}, 0.683 \mathrm{mmol})$ in $\mathrm{CH}_{2} \mathrm{Cl}_{2}(7 \mathrm{~mL})$ was cooled to $-78{ }^{\circ} \mathrm{C}$ and a $1.5 \mathrm{M}$ solution of DIBAL-H in toluene $(0.546 \mathrm{~mL}, 0.819 \mathrm{mmol})$ was added dropwise. After $5 \mathrm{~h}$, acetic anhydride $(0.644 \mathrm{~mL}, 6.82 \mathrm{mmol})$, pyridine $(0.442 \mathrm{~mL}, 5.46 \mathrm{mmol})$, and 4dimethylaminopyridine $(0.200 \mathrm{~g}, 1.63 \mathrm{mmol})$ were added..$^{5}$ The reaction mixture was allowed to warm slowly over $0.5 \mathrm{~h}$ to $23{ }^{\circ} \mathrm{C}$ and it was stirred for $24 \mathrm{~h}$. Saturated aqueous $\mathrm{NH}_{4} \mathrm{Cl}(3 \mathrm{~mL})$ was added, and the $\mathrm{CH}_{2} \mathrm{Cl}_{2} \mathrm{was}$ removed in vacuo. The residue was dissolved in MTBE $(7 \mathrm{~mL})$. The organic layer was washed with saturated aqueous $\mathrm{Na}_{2} \mathrm{HPO}_{4}(4 \square 4 \mathrm{~mL}), \mathrm{NaH}_{2} \mathrm{PO}_{4}(4 \square 4 \mathrm{~mL})$, and $\mathrm{CuSO}_{4}(5 \square 4 \mathrm{~mL})$, filtered through $\mathrm{Na}_{2} \mathrm{SO}_{4}$, and concentrated in vacuo. The resulting oil was purified by flash column chromatography (hexanes to 1:4 $\mathrm{Et}_{2} \mathrm{O} /$ hexanes $)$ to afford one isomer as a colorless oil: $(0.113 \mathrm{~g}, 63 \%):{ }^{1} \mathrm{H} \mathrm{NMR}\left(500 \mathrm{MHz}, \mathrm{CDCl}_{3}\right) \square 7.36-7.27$ $(\mathrm{m}, 5 \mathrm{H}), 5.70(\mathrm{dd}, J=9.4,2.3,1 \mathrm{H}), 4.60-4.54(\mathrm{~m}, 2 \mathrm{H}), 3.82-3.78(\mathrm{~m}, 1 \mathrm{H}), 3.59-3.55(\mathrm{dd}, J=10.1,5.5,1 \mathrm{H})$, 3.50-3.47 (dd, $J=10.1,4.9,1 \mathrm{H}), 2.10(\mathrm{~s}, 3 \mathrm{H}), 1.94(\mathrm{~m}, 1 \mathrm{H}), 1.83(\mathrm{~m}, 1 \mathrm{H}) 1.65-1.56(\mathrm{~m}, 2 \mathrm{H}), 1.54-1.48(\mathrm{~m}$, 1H), 1.39-1.34 (m, 1H); ${ }^{13} \mathrm{C}$ NMR (125 MHz, $\left.\mathrm{CDCl}_{3}\right) \square 169.6,138.4,128.6,128.0,127.8,95.1,76.3,73.6$, 72.9, 30.1, 27.2, 21.5, 21.4; IR (thin film) 2941, 2863, 1743, 1237, 1223, $1040 \mathrm{~cm}^{-1}$; HRMS (EI/GCMS) $\mathrm{m} / \mathrm{z}$ calcd for $\mathrm{C}_{15} \mathrm{H}_{20} \mathrm{NaO}_{4}(\mathrm{M}+\mathrm{Na})^{+} 287.1259$, found 287.1258 . 
B. Lyxose Acetate 13.

Lyxose acetate 13 was prepared from D-lyxose according to the following procedure:

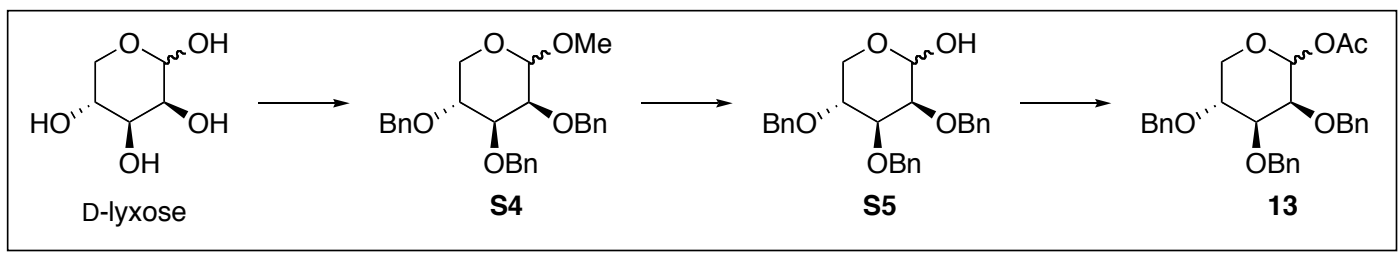

2,3,4-Tri- $\boldsymbol{O}$-benzyl-1-methoxylyxopyranose (S4): ${ }^{6}$ A solution of D-lyxose (2 g, $\left.13.0 \mathrm{mmol}\right)$ and Dowex-50 $\mathrm{H}^{+}(0.67 \mathrm{~g})$ in $\mathrm{MeOH}(13 \mathrm{~mL})$ was heated to $95^{\circ} \mathrm{C}$ for $24 \mathrm{~h}$. The reaction mixture was allowed to cool to $23^{\circ} \mathrm{C}$. The reaction mixture was filtered with $\mathrm{MeOH}(25 \mathrm{~mL})$ and concentrated in vacuo. The resulting oil was purified by flash chromatography over fluorosil (chloroform to 1:5 MeOH/chloroform) to afford one isomer of the methyl lyxopyranoside ${ }^{6}$ as a colorless oil. Sodium hydride $(1.09 \mathrm{~g}, 66.7 \mathrm{mmol})$ was added to a cooled (0 $\left.{ }^{\circ} \mathrm{C}\right)$ solution of methyl lyxopyranoside $(2.19 \mathrm{~g}, 13.4 \mathrm{mmol})$ in DMF $(119 \mathrm{~mL})$. The reaction mixture was allowed to warm to $23{ }^{\circ} \mathrm{C}$ and the mixture was stirred for $2 \mathrm{~h}$. The mixture was then cooled to $0{ }^{\circ} \mathrm{C}$ and benzyl bromide (32.4 g, $190.0 \mathrm{mmol})$ was added dropwise. The reaction mixture was allowed to warm slowly to $23{ }^{\circ} \mathrm{C}$ and the mixture was stirred for $24 \mathrm{~h}$ before addition of $\mathrm{H}_{2} \mathrm{O}(50 \mathrm{~mL})$. The aqueous layer was extracted with $\mathrm{Et}_{2} \mathrm{O}(3 \square 20 \mathrm{~mL})$, and the combined organic layers were washed with brine $(25 \mathrm{~mL})$, dried over $\mathrm{MgSO}_{4}$, and concentrated in vacuo. The resulting oil was purified by flash column chromatography (hexanes to 1:9 $\mathrm{Et}_{2} \mathrm{O} /$ hexanes $)$ to afford one isomer as a colorless oil $(2.17 \mathrm{~g}, 38 \%):{ }^{1} \mathrm{H} \mathrm{NMR}\left(500 \mathrm{MHz}, \mathrm{CDCl}_{3}\right) \square 7.36-7.24$ $(\mathrm{m}, 15 \mathrm{H}), 4.76-4.61(\mathrm{~m}, 7 \mathrm{H}), 3.92(\mathrm{~m}, 1 \mathrm{H}), 3.82-3.74(\mathrm{~m}, 3 \mathrm{H}), 3.54-3.50(\mathrm{~m}, 1 \mathrm{H}), 3.33(\mathrm{~s}, 3 \mathrm{H}) ;{ }^{13} \mathrm{C} \mathrm{NMR}(125$ $\left.\mathrm{MHz}, \mathrm{CDCl}_{3}\right) \square 139.2,139.1,138.9,128.80,128.78,128.77,128.4,128.14,128.07,128.05,128.03,127.95$, 100.39, 79.4, 75.9, 75.3, 73.7, 73.5, 73.2, 61.9, 55.5; IR (thin film) 3030, 2908, 1496, 1454, 1113, $1062 \mathrm{~cm}^{-1}$; HRMS (EI/GCMS) $m / z$ calcd for $\mathrm{C}_{27} \mathrm{H}_{30} \mathrm{NaO}_{5}(\mathrm{M}+\mathrm{Na})^{+}$457.1991, found 457.1988. Anal. Calcd for $\mathrm{C}_{27} \mathrm{H}_{30} \mathrm{O}_{5}$ : C, 74.63; H, 6.96. Found: C, 74.53; H, 6.99.

2,3,4-Tri- $\boldsymbol{O}$-benzyllyxopyranose-1-ol (S5): A mixture of $\mathbf{S 4}(2.17 \mathrm{~g}, 5.00 \mathrm{mmol})$ and $88: 12 \mathrm{AcOH}: 2 \mathrm{~N}$ $\mathrm{H}_{2} \mathrm{SO}_{4}(22 \mathrm{~mL})$ was stirred at $90{ }^{\circ} \mathrm{C}$ for $24 \mathrm{~h}$. The reaction mixture was cooled to $23{ }^{\circ} \mathrm{C}$ and the acid was neutralized with saturated $\mathrm{NaHCO}_{3}$, extracted with $\mathrm{CH}_{2} \mathrm{Cl}_{2}(3 \square 12 \mathrm{~mL})$, filtered through $\mathrm{Na}_{2} \mathrm{SO}_{4}$, and concentrated in vacuo. The resulting oil was purified by flash column chromatography (hexanes to 1:1 $\mathrm{Et}_{2} \mathrm{O} /$ hexanes) to afford the product (as a 1:1 mixture of isomers) as a colorless oil $(1.15 \mathrm{~g}, 52 \%)$ : ${ }^{1} \mathrm{H}$ NMR $\left(500 \mathrm{MHz}, \mathrm{CDCl}_{3}\right) \square 7.35-7.23(\mathrm{~m}, 30 \mathrm{H}), 5.18(\mathrm{~m}, 1 \mathrm{H}), 5.10(\mathrm{~m}, 1 \mathrm{H}), 4.74-4.50(\mathrm{~m}, 12 \mathrm{H}), 4.08(\mathrm{~m}, 1 \mathrm{H})$, 3.89-3.75 (m, 6H), 3.70-3.60 (m, 4H), $3.03(\mathrm{~m}, 1 \mathrm{H}) ;{ }^{13} \mathrm{C}$ NMR $\left(125 \mathrm{MHz}, \mathrm{CDCl}_{3}\right) \square 139.0,138.8,138.4,138.2$, $137.8,129.0,128.94,128.85,128.83,128.80,128.6,128.5,128.43,128.39,128.34,128.31,128.30,128.2$, 128.12, 128.05, 94.3, 93.4, 78.0, 77.1, 77.0, 75.3, 74.9, 74.56, 73.56, 73.42, 73.37, 73.0, 72.0, 71.9, 62.6, 58.0; IR (thin film) 3412, 3031, 2921, 2877, 1454, $1094 \mathrm{~cm}^{-1}$; HRMS (EI/GCMS) $m / z$ calcd for $\mathrm{C}_{26} \mathrm{H}_{28} \mathrm{NaO}_{5}(\mathrm{M}+$ $\mathrm{Na})^{+} 443.1834$, found 443.1813 .

Lyxose acetate 13: A solution of $\mathbf{S 5}(0.538 \mathrm{~g}, 1.28 \mathrm{mmol})$, acetic anhydride $(0.604 \mathrm{~mL}, 6.40 \mathrm{mmol})$, pyridine $(0.414 \mathrm{~mL}, 5.12 \mathrm{mmol})$, and 4-dimethylaminopyridine $(0.314 \mathrm{~g}, 2.56 \mathrm{mmol})$ in $\mathrm{CH}_{2} \mathrm{Cl}_{2}(13 \mathrm{~mL})$ was stirred for $12 \mathrm{~h}$. Saturated aqueous $\mathrm{NH}_{4} \mathrm{Cl}(5 \mathrm{~mL})$ was added and the $\mathrm{CH}_{2} \mathrm{Cl}_{2}$ layer was separated and removed in vacuo. The residue was dissolved in MTBE $(13 \mathrm{~mL})$ and washed with aqueous $\mathrm{Na}_{2} \mathrm{HPO}_{4}(3 \square 5 \mathrm{~mL}), \mathrm{NaH}_{2} \mathrm{PO}_{4}(3 \square 5$ $\mathrm{mL})$, and $\mathrm{CuSO}_{4}(5 \square 5 \mathrm{~mL})$. The organic phases were filtered through $\mathrm{Na}_{2} \mathrm{SO}_{4}$ and concentrated in vacuo. The resulting oil was purified by flash chromatography (hexanes to 1:10 $\mathrm{Et}_{2} \mathrm{O} /$ hexanes) to afford one isomer as a colorless oil $(0.377 \mathrm{~g}, 64 \%)$ : ${ }^{1} \mathrm{H}$ NMR $\left(500 \mathrm{MHz}, \mathrm{CDCl}_{3}\right) \square 7.36-7.27(\mathrm{~m}, 15 \mathrm{H}), 6.05(\mathrm{~m}, 1 \mathrm{H}), 4.71-4.59(\mathrm{~m}$, $6 \mathrm{H}), 3.92-3.89(\mathrm{~m}, 2 \mathrm{H}), 3.81(\mathrm{~m}, 1 \mathrm{H}), 3.73(\mathrm{~m}, 1 \mathrm{H}), 3.63(\mathrm{~m}, 1 \mathrm{H}), 2.04(\mathrm{~s}, 3 \mathrm{H}) ;{ }^{13} \mathrm{C}$ NMR $\left(125 \mathrm{MHz} \mathrm{CDCl}_{3}\right) \square$ 169.2, 138.3, 138.2, 137.8, 128.40, 128.38, 128.3, 127.9, 127.79, 127.77, 127.75, 127.7, 127.6, 92.0, 77.7, 74.4, 
74.2, 73.0, 72.9, 72.8, 63.4, 21.0; IR (thin film) 3031, 2872, 1748, 1454, 1370, 1231, $1102 \mathrm{~cm}^{-1}$; HRMS (EI/GCMS) $m / z$ calcd for $\mathrm{C}_{28} \mathrm{H}_{30} \mathrm{NaO}_{6}(\mathrm{M}+\mathrm{Na})^{+} 485.1940$, found 485.1930 .

C. Ribose Acetate 22.

Ribose acetate $\mathbf{2 2}$ was prepared from D-ribose according to the following procedure:

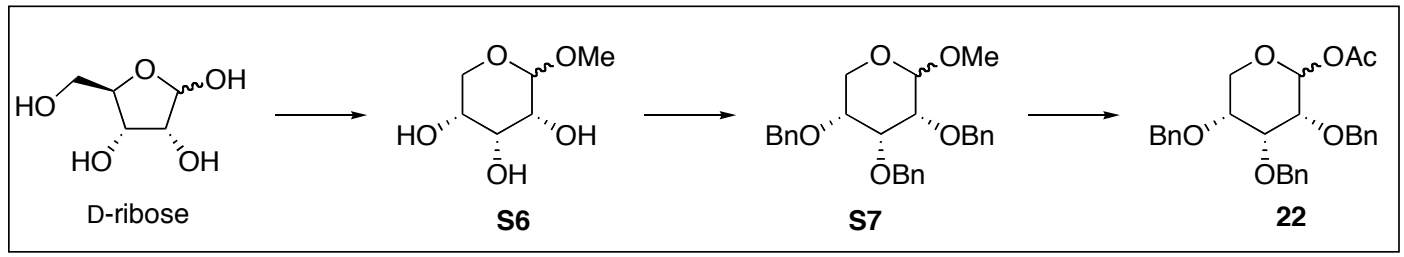

2,3,4-Tri- $\boldsymbol{O}$-benzyl-1-methoxyribopyranose (S7): Sodium hydride $(0.870 \mathrm{~g}, 36.0 \mathrm{mmol})$ was added to a cooled $\left(0{ }^{\circ} \mathrm{C}\right)$ solution of methyl ribopyranoside ${ }^{7} \mathbf{S 6}(0.877 \mathrm{~g}, 5.34 \mathrm{mmol})$ in DMF $(48 \mathrm{~mL})$. The reaction mixture was allowed to warm to $23{ }^{\circ} \mathrm{C}$ and the mixture was stirred for $2 \mathrm{~h}$. The mixture was then cooled to $0{ }^{\circ} \mathrm{C}$ and benzyl bromide $(13 \mathrm{~g}, 76 \mathrm{mmol})$ was added dropwise. The reaction mixture was allowed to warm slowly to $23{ }^{\circ} \mathrm{C}$ and stirred for $24 \mathrm{~h}$ before addition of $\mathrm{H}_{2} \mathrm{O}(20 \mathrm{~mL})$. The aqueous layer was extracted with $\mathrm{Et}_{2} \mathrm{O}(3 \square 10$ $\mathrm{mL})$, and the combined organic layers were washed with brine $(20 \mathrm{~mL})$, dried over $\mathrm{MgSO}_{4}$, and concentrated in vасио. The resulting oil was purified by flash column chromatography (hexanes to $1: 9 \mathrm{Et}_{2} \mathrm{O} / \mathrm{hexanes}$ ) to afford one isomer as a colorless oil $(1.92 \mathrm{~g}, 83 \%)$ : ${ }^{1} \mathrm{H}$ NMR $\left(500 \mathrm{MHz}, \mathrm{CDCl}_{3}\right) \square 7.40-7.27(\mathrm{~m}, 15 \mathrm{H}), 4.83-4.78(\mathrm{~m}$, $3 \mathrm{H}), 4.72(\mathrm{~m}, 1 \mathrm{H}), 4.62(\mathrm{~d}, J=12.2,1 \mathrm{H}), 4.55-4.49(\mathrm{~m}, 2 \mathrm{H}), 4.04(\mathrm{~m}, 1 \mathrm{H}), 3.86-3.82(\mathrm{dd}, J=10.9,9.5,1 \mathrm{H})$, 3.79-3.76 (dd, $J=11.0,4.1,1 \mathrm{H}), 3.53-3.50(\mathrm{ddd}, J=9.4,4.7,2.5,1 \mathrm{H}), 3.47(\mathrm{~s}, 3 \mathrm{H}), 3.26-3.24(\mathrm{dd}, J=7.0$, 2.7, 1H); ${ }^{1} \mathrm{H}$ NMR (500 MHz, $\left.\mathrm{C}_{6} \mathrm{D}_{6}\right) \square 7.50(\mathrm{~m}, 2 \mathrm{H}), 7.39(\mathrm{~m}, 2 \mathrm{H}), 7.22-7.08(\mathrm{~m}, 11 \mathrm{H}), 4.93-4.86(\mathrm{~m}, 4 \mathrm{H}), 4.62$ $(\mathrm{d}, J=12.2,1 \mathrm{H}), 4.23-4.14(\mathrm{~m}, 2 \mathrm{H}), 4.00-3.96(\mathrm{~m}, 2 \mathrm{H}), 3.80(\mathrm{dd}, J=10.8,4.1,1 \mathrm{H}), 3.32(\mathrm{~s}, 3 \mathrm{H}), 3.31-3.26$ $(\mathrm{m}, 2 \mathrm{H}) ;{ }^{13} \mathrm{C}$ NMR $\left(125 \mathrm{MHz}, \mathrm{CDCl}_{3}\right) \square 139.5,139.3,128.9,128.8,128.7,128.3,128.2,128.1,128.03,127.97$, $127.9,102.5,78.7,76.0,75.7,74.3,73.4,71.9,62.6,57.2 ;{ }^{13} \mathrm{C}$ NMR $\left(125 \mathrm{MHz}, \mathrm{C}_{6} \mathrm{D}_{6}\right) \square 140.1,140.0,139.3$, 128.86, 128.85, 128.7, 128.5, 128.06, 128.04, 127.91, 127.85, 127.8, 103.0, 79.5, 77.0, 76.5, 75.1, 73.4, 71.6, 62.6, 56.7; IR (thin film) 3030, 2879, 1497, 1207, $1089 \mathrm{~cm}^{-1}$; HRMS (EI/GCMS) $m$ / z calcd for $\mathrm{C}_{27} \mathrm{H}_{30} \mathrm{NaO}_{5}(\mathrm{M}$ $+\mathrm{Na})^{+}$457.1991, found 457.1991. Anal. Calcd for $\mathrm{C}_{27} \mathrm{H}_{30} \mathrm{O}_{5}: \mathrm{C}, 74.63 ; \mathrm{H}, 6.96$. Found: C, 74.79; $\mathrm{H}, 6.95$.

Ribose acetate 22: A mixture of $\mathbf{S 7}(1.85 \mathrm{~g}, 4.26 \mathrm{mmol})$ and 88:12 AcOH:2 N H $\mathrm{SO}_{4}(20 \mathrm{~mL})$ was stirred at 90 ${ }^{\circ} \mathrm{C}$ for $2 \mathrm{~h}$. The reaction mixture was cooled to $23{ }^{\circ} \mathrm{C}$ and the acid was neutralized with saturated $\mathrm{NaHCO}_{3}$, extracted with $\mathrm{CH}_{2} \mathrm{Cl}_{2}(3 \square 8 \mathrm{~mL})$, filtered through $\mathrm{Na}_{2} \mathrm{SO}_{4}$, and concentrated in vacuo. The resulting oil was purified by flash column chromatography (hexanes to $1: 1 \mathrm{Et}_{2} \mathrm{O} /$ hexanes) to afford the product (as a 1:1 mixture of isomers) as a colorless oil $(0.561 \mathrm{~g}, 31 \%)$. A solution of 2,3,4-tri- $O$-benzyl-ribopyranose-1-ol (0.362 $\mathrm{g}$, $0.862 \mathrm{mmol})$, acetic anhydride $(0.407 \mathrm{~mL}, 4.31 \mathrm{mmol})$, pyridine $(0.279 \mathrm{~mL}, 3.45 \mathrm{mmol})$, and 4dimethylaminopyridine $(0.212 \mathrm{~g}, 1.72 \mathrm{mmol})$ in $\mathrm{CH}_{2} \mathrm{Cl}_{2}(9 \mathrm{~mL})$ was stirred for $12 \mathrm{~h}$. Saturated aqueous $\mathrm{NH}_{4} \mathrm{Cl}$ (4 mL) was added and the $\mathrm{CH}_{2} \mathrm{Cl}_{2}$ layer was separated and concentrated in vacuo. The residue was dissolved in MTBE (9 mL) and washed with aqueous $\mathrm{Na}_{2} \mathrm{HPO}_{4}(3 \square 4 \mathrm{~mL}), \mathrm{NaH}_{2} \mathrm{PO}_{4}(3 \square 4 \mathrm{~mL})$, and $\mathrm{CuSO}_{4}(5 \square 4 \mathrm{~mL})$. The organic phases were filtered through $\mathrm{Na}_{2} \mathrm{SO}_{4}$ and concentrated in vacuo. The resulting oil was purified by flash chromatography (hexanes to $1: 10 \mathrm{Et}_{2} \mathrm{O} /$ hexanes) to afford the product (as a 1:1 mixture of anomers) as a colorless oil $(0.371 \mathrm{~g}, 93 \%):{ }^{1} \mathrm{H}$ NMR $\left(500 \mathrm{MHz}, \mathrm{CDCl}_{3}\right) \square 7.53-7.32(\mathrm{~m}, 30 \mathrm{H}), 6.30(\mathrm{~m}, 1 \mathrm{H}), 6.10(\mathrm{~m}, 1 \mathrm{H})$, $4.97(\mathrm{~m}, 2 \mathrm{H}), 4.73(\mathrm{bs}, 2 \mathrm{H}), 4.71(\mathrm{~m}, 3 \mathrm{H}), 4.66-4.59(\mathrm{~m}, 5 \mathrm{H}), 4.27(\mathrm{~m}, 1 \mathrm{H}), 4.20(\mathrm{~m}, 2 \mathrm{H}), 4.10(\mathrm{~m}, 1 \mathrm{H}), 3.89$ $(\mathrm{m}, 1 \mathrm{H}), 3.68(\mathrm{~m}, 1 \mathrm{H}), 3.63-3.56(\mathrm{~m}, 3 \mathrm{H}), 3.45(\mathrm{~m}, 1 \mathrm{H}), 2.18(\mathrm{~s}, 3 \mathrm{H}), 2.14(\mathrm{~s}, 3 \mathrm{H}) ;{ }^{13} \mathrm{C} \mathrm{NMR}(125 \mathrm{MHz}$, $\left.\mathrm{CDCl}_{3}\right) \square 171.0,169.8,139.8,139.2,138.6,138.5,138.4,138.2,129.0,128.91,128.90,128.7,128.5,128.4$, 128.30, 128.26, 128.24, 128.19, 128.03, 127.99, 127.94, 127.90, 127.6, 93.1, 89.4, 77.7, 75.9, 75.2, 74.9, 74.5, 74.3, 74.0, 72.9, 72.1, 71.9, 71.4, 63.5, 59.3, 21.7; IR (thin film) 3030, 2882, 1748, 1223, $1074 \mathrm{~cm}^{-1}$; HRMS (EI/GCMS) $m / z$ calcd for $\mathrm{C}_{28} \mathrm{H}_{30} \mathrm{NaO}_{6}(\mathrm{M}+\mathrm{Na})^{+}$485.1940, found 485.1934. Anal. Calcd for $\mathrm{C}_{28} \mathrm{H}_{30} \mathrm{O}_{6}: \mathrm{C}_{\text {, }}$ 72.71; H, 6.54. Found: C, 72.95; H, 6.52. 
D. Xylose Acetate 26.

Xylose acetate $\mathbf{2 6}$ was prepared from methyl xylopyranoside $\mathbf{S 8}$ according to the following procedure:

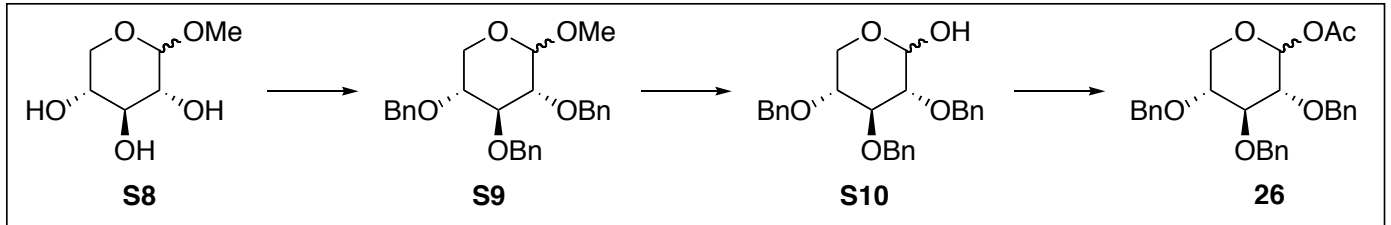

2,3,4-Tri-O-benzyl-1-methoxyxylopyranose (S9): Sodium hydride (4.27 g, $178 \mathrm{mmol}$ ) was added to a cooled $\left(0{ }^{\circ} \mathrm{C}\right)$ solution of methyl xylopyranoside ${ }^{8} \mathbf{S 8}(4.00 \mathrm{~g}, 24.4 \mathrm{mmol})$ in DMF $(218 \mathrm{~mL})$. The reaction mixture was warmed to $23{ }^{\circ} \mathrm{C}$ and the mixture was stirred for $2 \mathrm{~h}$. The mixture was then cooled to $0{ }^{\circ} \mathrm{C}$ and benzyl bromide (59.2 g, $346.0 \mathrm{mmol}$ ) was added dropwise. The reaction mixture was allowed to warm slowly to $23^{\circ} \mathrm{C}$ and stirred for $24 \mathrm{~h}$ before addition of $\mathrm{H}_{2} \mathrm{O}(100 \mathrm{~mL})$. The aqueous layer was extracted with $\mathrm{Et}_{2} \mathrm{O}(3 \square 40 \mathrm{~mL})$, and the combined organic layers were washed with brine $(70 \mathrm{~mL})$, dried over $\mathrm{MgSO}_{4}$, and concentrated in vacuo. The resulting oil was purified by flash column chromatography (hexanes to $1: 9 \mathrm{Et}_{2} \mathrm{O} / \mathrm{hexanes}$ ) to afford one isomer as a white solid (5.20 g, 49\%): ${ }^{1} \mathrm{H} \mathrm{NMR}\left(500 \mathrm{MHz}, \mathrm{CDCl}_{3}\right) \square 7.35-7.23(\mathrm{~m}, 15 \mathrm{H}), 4.89-4.83(\mathrm{~m}, 3 \mathrm{H})$, 4.74-4.69 (m, 2H), $4.61(\mathrm{~d}, J=11.6,1 \mathrm{H}), 4.25(\mathrm{~d}, J=7.6,1 \mathrm{H}), 3.95-3.92(\mathrm{dd}, J=11.8,5.0,1 \mathrm{H}), 3.63-3.55$ (m, $2 \mathrm{H}), 3.53(\mathrm{~s}, 3 \mathrm{H}), 3.35(\mathrm{t}, J=8.0,1 \mathrm{H}), 3.21(\mathrm{dd}, J=11.6,9.8,1 \mathrm{H}) ;{ }^{13} \mathrm{C} \mathrm{NMR}\left(125 \mathrm{MHz}, \mathrm{CDCl}_{3}\right) \square 138.6$, $138.5,138.1,128.4,128.3,128.00,127.95,127.83,127.82,127.60,127.58,105.2,83.6,81.9,77.8,75.6,74.8$, 73.4, 63.8, 57.0; IR (thin film) 2922, 2858, 1466, 1453, $1090 \mathrm{~cm}^{-1}$; HRMS (EI/GCMS) $\mathrm{m} / \mathrm{z}$ calcd for $\mathrm{C}_{27} \mathrm{H}_{30} \mathrm{NaO}_{5}(\mathrm{M}+\mathrm{Na})^{+}$457.1991, found 457.1992. Anal. Calcd for $\mathrm{C}_{27} \mathrm{H}_{30} \mathrm{O}_{5}: \mathrm{C}, 74.63 ; \mathrm{H}, 6.96$. Found: $\mathrm{C}$, $74.60 ; \mathrm{H}, 6.98$.

2,3,4-Tri-O-benzylxylopyranose-1-ol (S10): A mixture of S9 (5.18 g, $11.9 \mathrm{mmol})$ and 88:12 AcOH:2 N $\mathrm{H}_{2} \mathrm{SO}_{4}(53 \mathrm{~mL})$ was stirred at $90{ }^{\circ} \mathrm{C}$ for $24 \mathrm{~h}$. The reaction mixture was cooled to $23{ }^{\circ} \mathrm{C}$ and the acid was neutralized with saturated $\mathrm{NaHCO}_{3}$, extracted with $\mathrm{CH}_{2} \mathrm{Cl}_{2}(3 \square 20 \mathrm{~mL})$, filtered through $\mathrm{Na}_{2} \mathrm{SO}_{4}$, and concentrated in vacuo. The resulting oil was purified by flash column chromatography (hexanes to 1:1 $\mathrm{Et}_{2} \mathrm{O} /$ hexanes) to afford the product ${ }^{8}$ (as a 1:1 mixture of isomers) as a white solid $(2.33 \mathrm{~g}, 47 \%)$ : ${ }^{1} \mathrm{H}$ NMR (500 $\left.\mathrm{MHz} \mathrm{CDCl}_{3}\right) \square 7.36-7.26(\mathrm{~m}, 30 \mathrm{H}), 5.11(\mathrm{bs}, 1 \mathrm{H}), 4.86(\mathrm{~m}, 5 \mathrm{H}), 4.78-4.61(\mathrm{~m}, 8 \mathrm{H}), 3.92(\mathrm{~m}, 1 \mathrm{H}), 3.86(\mathrm{~m}$, 2H), 3.70-3.49 (m, 4H), 3.47-3.40 (m, 1H), 3.39-3.25 (m, 1H), $3.10(\mathrm{~m}, 1 \mathrm{H}), 2.91(\mathrm{~m}, 1 \mathrm{H}) ;{ }^{13} \mathrm{C}$ NMR $(125$ $\left.\mathrm{MHz}, \mathrm{CDCl}_{3}\right) \square 138.6,138.5,138.3,138.2,138.1,137.8,128.52,128.48,128.45,128.43,128.39,128.10$, $128.05,128.03,127.99,127.97,127.9,127.83,127.81,127.80,127.69,127.68,97.7,91.5,83.1,82.3,80.5$, 79.4, 77.5, 77.4, 75.50, 75.49, 74.8, 73.5, 73.3, 73.2, 63.7, 60.4; IR (thin film) 3433, 2920, 2865, 1454, 1092 , $1072 \mathrm{~cm}^{-1}$; HRMS (EI/GCMS) $m / z$ calcd for $\mathrm{C}_{26} \mathrm{H}_{28} \mathrm{NaO}_{5}(\mathrm{M}+\mathrm{Na})^{+} 443.1834$, found 443.1828 .

2,3,4-Tri- $\boldsymbol{O}$-benzylxylopyranose-1-acetate (26): A solution of $\mathbf{S 1 0}$ (0.540 g, $1.28 \mathrm{mmol})$, acetic anhydride $(0.606 \mathrm{~mL}, 6.42 \mathrm{mmol})$, pyridine $(0.418 \mathrm{~mL}, 5.14 \mathrm{mmol})$, and 4-dimethylaminopyridine $(0.316 \mathrm{~g}, 2.56 \mathrm{mmol})$ in $\mathrm{CH}_{2} \mathrm{Cl}_{2}(13 \mathrm{~mL})$ was stirred for $12 \mathrm{~h}$. Saturated aqueous $\mathrm{NH}_{4} \mathrm{Cl}(5 \mathrm{~mL})$ was added and the $\mathrm{CH}_{2} \mathrm{Cl}_{2}$ layer was separated and removed in vacuo. The residue was dissolved in MTBE (13 mL) and washed with aqueous $\mathrm{Na}_{2} \mathrm{HPO}_{4}(3 \square 5 \mathrm{~mL}), \mathrm{NaH}_{2} \mathrm{PO}_{4}(3 \square 5 \mathrm{~mL})$, and $\mathrm{CuSO}_{4}(5 \square 5 \mathrm{~mL})$. The organic phases were filtered through $\mathrm{Na}_{2} \mathrm{SO}_{4}$ and concentrated in vacuo. The resulting oil was purified by flash chromatography (hexanes to 1:10 $\mathrm{Et}_{2} \mathrm{O} /$ hexanes) to afford the product (as a 1.3:1 mixture of anomers) as a colorless oil $(0.576 \mathrm{~g}, 97 \%):{ }^{1} \mathrm{H} \mathrm{NMR}$ $\left(500 \mathrm{MHz}, \mathrm{CDCl}_{3}\right) \square 7.35-7.26(\mathrm{~m}, 30 \mathrm{H}), 6.22(\mathrm{~d}, J=3.6,1 \mathrm{H}), 5.55(\mathrm{~d}, J=7.9,1 \mathrm{H}), 4.90-4.60(\mathrm{~m}, 12 \mathrm{H})$, 3.94-3.91 (dd, $J=11.5,5.0,1 \mathrm{H}), 3.87(\mathrm{td}, J=9.0,1.4,1 \mathrm{H}), 3.74(\mathrm{~m}, 1 \mathrm{H}), 3.67-3.56(\mathrm{~m}, 5 \mathrm{H}), 3.49(\mathrm{t}, J=8.2$, $1 \mathrm{H}), 3.35(\mathrm{dd}, J=11.7,9.6,1 \mathrm{H}), 2.12(\mathrm{~s}, 3 \mathrm{H}), 2.00(\mathrm{~s}, 3 \mathrm{H}) ;{ }^{13} \mathrm{C}$ NMR $\left(125 \mathrm{MHz}, \mathrm{CDCl}_{3}\right) \square 170.1,169.8,139.3$, 139.0, 138.7, 138.6, 138.5, 138.2, 129.02, 128.99, 128.93, 128.91, 128.90, 128.86, 128.6, 128.53, 128.49, $128.45,128.44,128.37,128.35,128.3,128.23,128.17,95.2,90.6,84.2,81.7,81.0,79.1,78.1,78.0,76.2,76.1$, 75.6, 74.2, 73.9, 73.8, 65.1, 62.6, 21.6, 21.5; IR (thin film) 3031, 2895, 1753, 1227, $1090 \mathrm{~cm}^{-1}$; HRMS 
(EI/GCMS) $m$ / $z$ calcd for $\mathrm{C}_{28} \mathrm{H}_{30} \mathrm{NaO}_{6}(\mathrm{M}+\mathrm{Na})^{+}$485.1940, found 485.1930. Anal. Calcd for $\mathrm{C}_{28} \mathrm{H}_{30} \mathrm{O}_{6}: \mathrm{C}$, 72.71; H, 6.54. Found: C, 72.59; H, 6.64.

E. Arabinose Acetate 30.

Arabinose acetate $\mathbf{3 0}$ was prepared from methyl D-arabinose according to the following procedure:

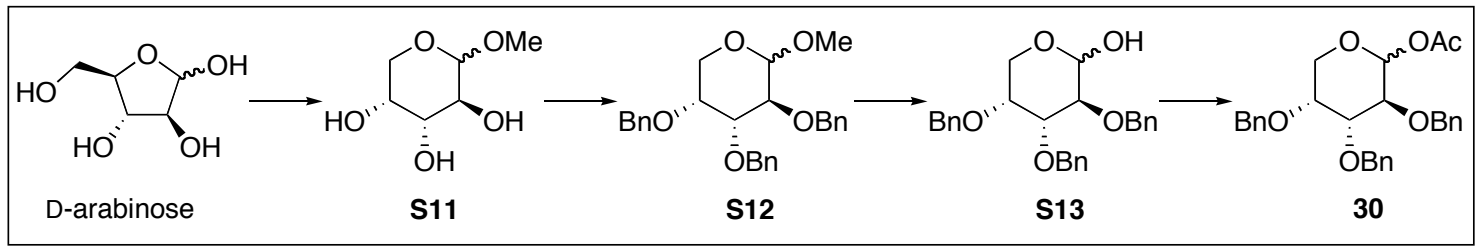

Methyl arabinopyranoside (S11): ${ }^{7}$ A solution of D-arabinose $(10 \mathrm{~g}, 67 \mathrm{mmol})$ in $1 \% \mathrm{HCl}$ in $\mathrm{MeOH}(100 \mathrm{~mL})$ was heated to $95^{\circ} \mathrm{C}$ for $24 \mathrm{~h}$. The reaction mixture was allowed to cool to $23{ }^{\circ} \mathrm{C}$, and $\mathrm{Ag}_{2} \mathrm{CO}_{3}(20 \mathrm{~g}, 73 \mathrm{mmol})$ was added and the mixture was stirred for $1 \mathrm{~h}$. Activated carbon was added to the reaction mixture, which was filtered through Celite with $\mathrm{MeOH}(25 \mathrm{~mL})$. The solution was concentrated in vacuo and recrystallized with ethyl acetate to afford one isomer as white crystals: ${ }^{1} \mathrm{H}$ NMR $\left(500 \mathrm{MHz}, d_{6}\right.$-DMSO) $\square 4.53-4.47(\mathrm{~m}, 3 \mathrm{H}), 3.68$ $(\mathrm{m}, 1 \mathrm{H}), 3.58-3.52(\mathrm{~m}, 3 \mathrm{H}), 3.43-3.40(\mathrm{dd}, J=11.9,3.0,1 \mathrm{H}), 3.33(\mathrm{~m}, 1 \mathrm{H}), 3.26(\mathrm{~s}, 3 \mathrm{H}) ;{ }^{13} \mathrm{C} \mathrm{NMR}(125 \mathrm{MHz}$, $d_{6}$-DMSO) $\square 100.5,69.0,68.5,68.2,62.8,54.7$; HRMS (EI/GCMS) $m / z$ calcd for $\mathrm{C}_{6} \mathrm{H}_{12} \mathrm{NaO}_{5}(\mathrm{M}+\mathrm{Na})^{+}$ 187.0582 , found 187.0577 .

2,3,4-Tri-O-benzyl-1-methoxyarabinopyranose (S12): Sodium hydride (1.06 g, $44.3 \mathrm{mmol})$ was added to a cooled $\left(0{ }^{\circ} \mathrm{C}\right)$ solution of methyl arabinopyranoside ${ }^{7} \mathbf{S 1 1}(0.995 \mathrm{~g}, 6.07 \mathrm{mmol})$ in DMF $(54 \mathrm{~mL})$. The reaction mixture was allowed to warm to $23{ }^{\circ} \mathrm{C}$ and the mixture was stirred for $2 \mathrm{~h}$. The mixture was then cooled to $0{ }^{\circ} \mathrm{C}$ and benzyl bromide $(14.7 \mathrm{~g}, 86.2 \mathrm{mmol})$ was added dropwise. The reaction mixture was allowed to warm slowly to $23{ }^{\circ} \mathrm{C}$ and the mixture was stirred for $24 \mathrm{~h}$ before addition of $\mathrm{H}_{2} \mathrm{O}(25 \mathrm{~mL})$. The aqueous layer was extracted with $\mathrm{Et}_{2} \mathrm{O}(3 \square 12 \mathrm{~mL})$, and the combined organic layers were washed with brine $(20 \mathrm{~mL})$, dried over $\mathrm{MgSO}_{4}$, and concentrated in vacuo. The resulting oil was purified by flash column chromatography (hexanes to 1:9 $\mathrm{Et}_{2} \mathrm{O} /$ hexanes) to afford one isomer as a colorless oil $(2.33 \mathrm{~g}, 86 \%):{ }^{1} \mathrm{H} \mathrm{NMR}\left(500 \mathrm{MHz}, \mathrm{CDCl}_{3}\right) \square$ 7.40-7.27 (m, 15H), $4.87(\mathrm{~d}, J=12.1,1 \mathrm{H}), 4.79-4.66(\mathrm{~m}, 6 \mathrm{H}), 4.05-4.02(\mathrm{dd}, J=9.7,3.5,1 \mathrm{H}), 3.91-3.89$ (dd, $J=9.7,3.2,1 \mathrm{H}), 3.77(\mathrm{~m}, 1 \mathrm{H}), 3.69-3.61(\mathrm{~m}, 2 \mathrm{H}), 3.40(\mathrm{~s}, 3 \mathrm{H}) ;{ }^{13} \mathrm{C} \mathrm{NMR}\left(125 \mathrm{MHz}, \mathrm{CDCl}_{3}\right) \square 139.1,139.0$, $138.7,128.8,128.59,128.57,128.3,128.1,127.89,127.87,127.85,127.8,127.2$, 99.6, 76.7, 74.4, 74.0, 73.1, 72.1, 65.6, 60.5, 55.8; IR (thin film) 3030, 2913, 1496, 1139, 1100, $1056 \mathrm{~cm}^{-1}$; HRMS (EI/GCMS) $\mathrm{m} / \mathrm{z}$ calcd for $\mathrm{C}_{27} \mathrm{H}_{30} \mathrm{NaO}_{5}(\mathrm{M}+\mathrm{Na})^{+}$457.1991, found 457.1978. Anal. Calcd for $\mathrm{C}_{27} \mathrm{H}_{30} \mathrm{O}_{5}: \mathrm{C}, 74.63 ; \mathrm{H}, 6.96$. Found: $\mathrm{C}$, $74.92 ; \mathrm{H}, 6.93$.

2,3,4-Tri-O-benzylarabinopyranose-1-ol (S13): A mixture of $\mathbf{S 1 2}(1.88 \mathrm{~g}, 4.32 \mathrm{mmol})$ and 88:12 AcOH:2 N $\mathrm{H}_{2} \mathrm{SO}_{4}(19 \mathrm{~mL})$ was stirred at $90{ }^{\circ} \mathrm{C}$ for $2 \mathrm{~h}$. The reaction mixture was cooled to $23{ }^{\circ} \mathrm{C}$ and the acid was neutralized with saturated $\mathrm{NaHCO}_{3}$, extracted with $\mathrm{CH}_{2} \mathrm{Cl}_{2}(3 \square 8 \mathrm{~mL})$, filtered through $\mathrm{Na}_{2} \mathrm{SO}_{4}$, and concentrated in vacuo. The resulting oil was purified by flash column chromatography (hexanes to 1:1 $\mathrm{Et}_{2} \mathrm{O} /$ hexanes) to afford the product (as a 1:1 mixture of isomers) as a white solid $(0.915 \mathrm{~g}, 50 \%)$ : ${ }^{1} \mathrm{H} \mathrm{NMR}$ $\left(500 \mathrm{MHz}, \mathrm{CDCl}_{3}\right) \square 7.34-7.24(\mathrm{~m}, 30 \mathrm{H}), 5.18(\mathrm{bs}, 1 \mathrm{H}), 4.87-4.52(\mathrm{~m}, 12 \mathrm{H}), 4.03(\mathrm{~m}, 1 \mathrm{H}), 3.89-3.82(\mathrm{~m}, 5 \mathrm{H})$, 3.79-3.75 (m, 2H), 3.65-3.60 (m, 2H), $3.26(\mathrm{~m}, 1 \mathrm{H}) ;{ }^{13} \mathrm{C} \mathrm{NMR}\left(125 \mathrm{MHz}, \mathrm{CDCl}_{3}\right) \square 138.7,138.5,138.4,138.2$, 138.0, 137.8, 128.9, 128.80, 128.78, 128.75, 128.74, 128.68, 128.66, 128.33, 128.29, 128.25, 128.20, 128.17 , 128.14, 128.09, 127.98, 127.95, 94.2, 92.4, 76.9, 76.6, 76.5, 75.8, 74.0, 73.9, 73.3, 73.2, 73.0, 72.3, 71.8, 61.2, 58.8; IR (thin film) 3411, 2872, 1454, 1094, 33030, $2919 \mathrm{~cm}^{-1}$; HRMS (EI/GCMS) $m / z$ calcd for $\mathrm{C}_{26} \mathrm{H}_{28} \mathrm{NaO}_{5}$ $(\mathrm{M}+\mathrm{Na})^{+} 443.1834$, found 443.1832 .

2,3,4-Tri- $\boldsymbol{O}$-benzylarabinopyranose-1-acetate (30): A solution of $\mathbf{S 1 3}(0.450 \mathrm{~g}, 1.07 \mathrm{mmol})$, acetic anhydride $(0.505 \mathrm{~mL}, 5.35 \mathrm{mmol})$, pyridine $(0.346 \mathrm{~mL}, 4.28 \mathrm{mmol})$, and 4-dimethylaminopyridine $(0.263 \mathrm{~g}, 2.14 \mathrm{mmol})$ in $\mathrm{CH}_{2} \mathrm{Cl}_{2}(11 \mathrm{~mL})$ was stirred for $12 \mathrm{~h}$. Saturated aqueous $\mathrm{NH}_{4} \mathrm{Cl}(4 \mathrm{~mL})$ was added and the $\mathrm{CH}_{2} \mathrm{Cl}_{2}$ layer was 
separated and removed in vacuo. The residue was dissolved in MTBE $(11 \mathrm{~mL})$ and washed with aqueous $\mathrm{Na}_{2} \mathrm{HPO}_{4}(3 \square 4 \mathrm{~mL}), \mathrm{NaH}_{2} \mathrm{PO}_{4}(3 \square 4 \mathrm{~mL})$, and $\mathrm{CuSO}_{4}(5 \square 4 \mathrm{~mL})$. The organic phases were filtered through $\mathrm{Na}_{2} \mathrm{SO}_{4}$ and concentrated in vacuo. The resulting oil was purified by flash chromatography (hexanes to 1:10 $\mathrm{Et}_{2} \mathrm{O} /$ hexanes) to afford the product (as a 1:1 mixture of anomers) as a colorless oil $(0.479 \mathrm{~g}, 97 \%)$ : ${ }^{1} \mathrm{H} \mathrm{NMR}$ $\left(500 \mathrm{MHz}, \mathrm{CDCl}_{3}\right) \square 7.37-7.23(\mathrm{~m}, 30 \mathrm{H}), 6.33(\mathrm{~d}, J=3.6,1 \mathrm{H}), 5.60(\mathrm{~d}, J=6.3,1 \mathrm{H}), 4.76-4.61(\mathrm{~m}, 12 \mathrm{H})$, 4.14-4.12 (dd, $J=9.5,3.5,1 \mathrm{H}), 4.05(\mathrm{dd}, J=12.4,4.4,1 \mathrm{H}), 3.89(\mathrm{dd}, J=8.0,6.4,1 \mathrm{H}), 3.86-3.81(\mathrm{~m}, 3 \mathrm{H})$, $3.76(\mathrm{~m}, 1 \mathrm{H}), 3.73-3.70(\mathrm{~m}, 1 \mathrm{H}), 3.64-3.62(\mathrm{dd}, J=8.0,3.2,1 \mathrm{H}), 3.45(\mathrm{~m}, 1 \mathrm{H}), 2.10(\mathrm{~s}, 3 \mathrm{H}), 2.04(\mathrm{~s}, 3 \mathrm{H}) ;{ }^{13} \mathrm{C}$ NMR $\left(125 \mathrm{MHz}, \mathrm{CDCl}_{3}\right) \square 170.13,170.11,139.0,138.72,138.65,138.6,138.5,129.02,129.00,128.90$, $128.89,128.86,128.8,128.53,128.49,128.42,128.40,128.37,128.3,128.23,128.21,128.20,128.13,128.06$, 128.0, 94.5, 91.8, 79.4, 77.5, 77.4, 75.7, 75.1, 74.0, 73.9, 73.1, 72.8, 72.4, 72.3, 71.9, 63.5, 63.0, 21.6, 21.5; IR (thin film) 3031, 2872, 1748, 1454, 1229, $1096 \mathrm{~cm}^{-1}$; HRMS (EI/GCMS) $m / z$ calcd for $\mathrm{C}_{28} \mathrm{H}_{30} \mathrm{NaO}_{6}(\mathrm{M}+\mathrm{Na})^{+}$ 485.1940, found 485.1945 .

\section{Nucleophilic substitution of acetate substrates}

Typical Allylation Procedure: Allyltrimethylsilane (4.0 equiv) was added to a solution of acetate $(0.15 \mathrm{M})$ in $\mathrm{CH}_{2} \mathrm{Cl}_{2}$, and the mixture was cooled to $-78^{\circ} \mathrm{C}$ and treated with the Lewis acid (1.2 equiv). The mixture was allowed to warm to $23{ }^{\circ} \mathrm{C}$ and quenched with saturated aqueous $\mathrm{Na}_{2} \mathrm{HPO}_{4}(1 \mathrm{~mL}$ per mmol of acetate). The layers were separated, and the aqueous layer was extracted three times with $\mathrm{CH}_{2} \mathrm{Cl}_{2}$ (1 mL per mmol of acetate), dried over $\mathrm{Na}_{2} \mathrm{SO}_{4}$, and concentrated in vacuo. The unpurified product ratios were determined using GC and confirmed using GCMS. The reported yields are of purified material.

Selectivities were determined by GC analysis and confirmed by ${ }^{1} \mathrm{H}$ NMR spectroscopy. The relative configurations of the products were determined using a combination of ${ }^{1} \mathrm{H}$ NMR coupling constant data and nuclear Overhauser effect (nOe) enhancements. The peaks in the ${ }^{1} \mathrm{H}$ NMR spectra were assigned using ${ }^{1} \mathrm{H} /{ }^{1} \mathrm{H}$ COSY experiments, ${ }^{1} \mathrm{H}$ NMR chemical shifts, and ${ }^{1} \mathrm{H}$ NMR coupling constants.
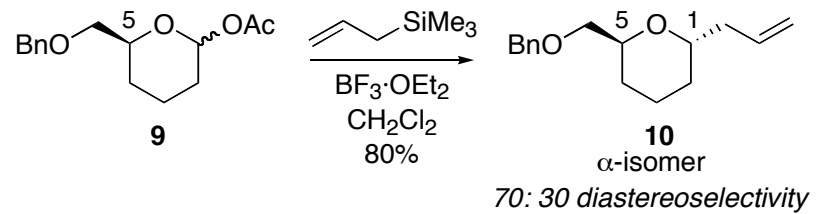

1-Allyl-5-benzyloxymethyltetrahydropyran (10): Under standard allylation conditions using $\mathrm{BF}_{3} \cdot \mathrm{OEt}_{2}$ as a Lewis acid, acetate $9(0.113 \mathrm{~g}, 0.429 \mathrm{mmol})$ afforded $\mathbf{1 0}(0.077 \mathrm{~g}, 73 \%)$ as a 70:30 1,5-trans:cis mixture of isomers. The oil was purified by flash chromatography (hexanes to 1:9 $\mathrm{Et}_{2} \mathrm{O}$ /hexanes) to afford the 1,5-trans product: ${ }^{1} \mathrm{H}$ NMR $\left(500 \mathrm{MHz}, \mathrm{CDCl}_{3}\right) \square 7.34-7.26(\mathrm{~m}, 5 \mathrm{H}), 5.85-5.77(\mathrm{~m}, 1 \mathrm{H}), 5.06(\mathrm{~m}, 2 \mathrm{H}), 4.56(\mathrm{~m}, 2 \mathrm{H})$, $3.93(\mathrm{~m}, 1 \mathrm{H}), 3.80(\mathrm{~m}, 1 \mathrm{H}), 3.58(\mathrm{dd}, J=9.9,6.3,1 \mathrm{H}), 3.46(\mathrm{dd}, J=9.9,5.3,1 \mathrm{H}), 2.48-2.43(\mathrm{~m}, 1 \mathrm{H})$, 2.26-2.20 (m, 1H), 1.67-1.55 (m, 4H), 1.46-1.37 (m, 2H); ${ }^{1} \mathrm{H}$ NMR (500 MHz, $\left.\mathrm{C}_{6} \mathrm{D}_{6}\right) \square 7.32-7.08(\mathrm{~m}, 5 \mathrm{H})$, 5.89-5.82 (m, 1H), 5.07-5.02 (m, 2H), 4.42-4.37 (m, 2H), 4.00-3.91 (ddd, $J=10.3,5.6,5.8,1 \mathrm{H}), 3.72-3.67$ (qd, $J=6.4,3.8,1 \mathrm{H}), 3.56-3.53(\mathrm{dd}, J=9.7,5.8,1 \mathrm{H}), 3.41-3.38(\mathrm{dd}, J=9.7,6.0,1 \mathrm{H}), 2.44-2.39(\mathrm{~m}, 1 \mathrm{H})$, 2.09-2.04 (m, 1H), $1.53(\mathrm{~m}, 1 \mathrm{H}), 1.36(\mathrm{~m}, 4 \mathrm{H}), 1.17(\mathrm{~m}, 1 \mathrm{H}) ;{ }^{13} \mathrm{C}$ NMR $\left(125 \mathrm{MHz}, \mathrm{CDCl}_{3}\right) \square 138.7,135.5$, 128.6, 127.9, 127.7, 116.8, 73.5, 71.9, 71.8, 70.3, 37.9, 29.1, 27.3, 18.6; IR (thin film) $\mathrm{cm}^{-1}$; HRMS (EI/GCMS) $m / z$ calcd for $\mathrm{C}_{16} \mathrm{H}_{22} \mathrm{NaO}_{2}(\mathrm{M}+\mathrm{Na})^{+} 269.1518$, found 269.1525 .

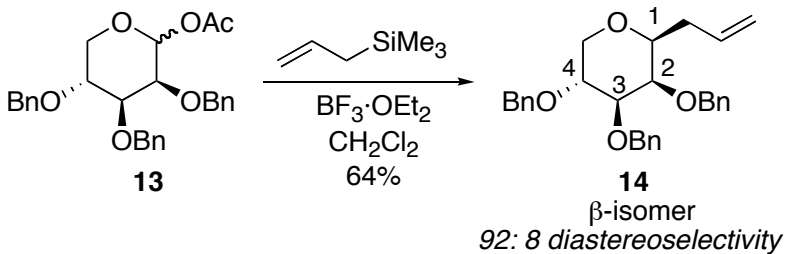


1-Allyl-2,3,4-tri- $\boldsymbol{O}$-benzyllyxopyranose (14): Under standard allylation conditions using $\mathrm{BF}_{3} \cdot \mathrm{OEt}_{2}$ as a Lewis acid, acetate $13(0.263 \mathrm{~g}, 0.569 \mathrm{mmol})$ afforded $14(0.377 \mathrm{~g}, 64 \%)$ as a 92:8 1,4-trans:cis mixture of isomers. The oil was purified by flash chromatography (hexanes to $1: 9 \mathrm{Et}_{2} \mathrm{O} /$ hexanes) to afford the 1,4-trans product: ${ }^{1} \mathrm{H}$ $\operatorname{NMR}\left(500 \mathrm{MHz}, \mathrm{CDCl}_{3}\right) \square 7.41-7.20(\mathrm{~m}, 15 \mathrm{H}), 5.69-5.65(\mathrm{~m}, 1 \mathrm{H}), 5.03-4.99(\mathrm{~m}, 3 \mathrm{H}), 4.84-4.77(\mathrm{~m}, 3 \mathrm{H})$, $4.65(\mathrm{~d}, J=11.5,1 \mathrm{H}$ and $\mathrm{d}, J=11.6,1 \mathrm{H}), 4.08-4.03(\mathrm{~m}, 2 \mathrm{H}), 3.77-3.75(\mathrm{~d}, J=2.6,1 \mathrm{H}), 3.57-3.51(\mathrm{dd}, J=8.8$, $2.8,1 \mathrm{H}), 3.26-3.24(\mathrm{t}, J=7.0,1 \mathrm{H}), 3.17-3.12(\mathrm{t}, J=12.6,1 \mathrm{H}), 2.44-2.40(\mathrm{~m}, 1 \mathrm{H}), 2.22-2.18(\mathrm{~m}, 1 \mathrm{H}) ;{ }^{13} \mathrm{C}$ NMR (125 MHz, $\left.\mathrm{CDCl}_{3}\right) \square 139.2,139.05,139.03,135.1,128.92,128.89,128.8,128.3,128.2,128.13,128.09$, 128.0, 117.8, 84.7, 79.5, 75.9, 75.7, 75.1, 74.0, 73.3, 69.2, 36.3; IR (thin film) 3030, 2860, 1496, 1454, 1362, 1129, $1093 \mathrm{~cm}^{-1}$; HRMS (EI/GCMS) $m / z$ calcd for $\mathrm{C}_{29} \mathrm{H}_{32} \mathrm{NaO}_{4}(\mathrm{M}+\mathrm{Na})^{+}$467.2198, found 467.2191. Anal. Calcd for $\mathrm{C}_{29} \mathrm{H}_{32} \mathrm{O}_{4}$ : C, 78.35; H, 7.26. Found: C, 78.29; H, 7.05.

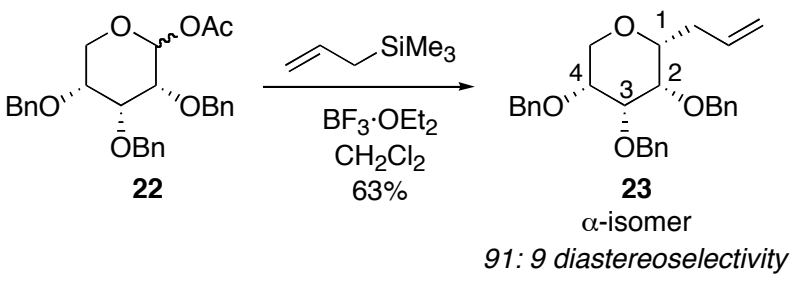

1-Allyl-2,3,4-tri- $\boldsymbol{O}$-benzylribopyranose (23): Under standard allylation conditions using $\mathrm{BF}_{3} \cdot \mathrm{OEt}_{2}$ as a Lewis acid, acetate $22(0.371 \mathrm{~g}, 0.802 \mathrm{mmol})$ afforded $\mathbf{5 1}(0.237 \mathrm{~g}, 63 \%)$ as a 91:9 1,4-cis:trans mixture of isomers. The oil was purified by flash chromatography (hexanes to 1:9 $\mathrm{Et}_{2} \mathrm{O} /$ hexanes) to afford the 1,4-cis product: ${ }^{1} \mathrm{H}$ $\operatorname{NMR}\left(500 \mathrm{MHz}, \mathrm{CDCl}_{3}\right) \square 7.47-7.31(\mathrm{~m}, 15 \mathrm{H}), 5.88-5.82(\mathrm{~m}, 1 \mathrm{H}), 5.16-5.09(\mathrm{~m}, 2 \mathrm{H}), 5.00(\mathrm{~d}, J=11.8,1 \mathrm{H})$, $4.86(\mathrm{~d}, J=12.5,1 \mathrm{H}), 4.80-4.67(\mathrm{~m}, 4 \mathrm{H}), 4.19-4.15(\mathrm{dd}, J=12.1,4.5,1 \mathrm{H}), 3.79-3.74(\mathrm{~m}, 3 \mathrm{H}), 3.55(\mathrm{~m}, 1 \mathrm{H})$, $3.52-3.49(\mathrm{dd}, J=12.1,2.6,1 \mathrm{H}), 2.85-2.79(\mathrm{~m}, 1 \mathrm{H}), 2.51-2.45(\mathrm{~m}, 1 \mathrm{H}) ;{ }^{1} \mathrm{H}$ NMR $\left(500 \mathrm{MHz}, \mathrm{C}_{6} \mathrm{D}_{6}\right) \square$ $7.40-7.08(\mathrm{~m}, 15 \mathrm{H}), 6.00-5.92(\mathrm{~m}, 1 \mathrm{H}), 5.16-5.06(\mathrm{~m}, 2 \mathrm{H}), 4.74(\mathrm{~m}, 1 \mathrm{H}), 4.70(\mathrm{~d}, J=12.1,1 \mathrm{H}), 4.55(\mathrm{~d}, J=$ $12.2,1 \mathrm{H}), 4.44-4.35(\mathrm{~m}, 3 \mathrm{H}), 4.07-4.03(\mathrm{dd}, J=11.6,6.2,1 \mathrm{H}), 3.60(\mathrm{~m}, 2 \mathrm{H}), 3.43(\mathrm{t}, J=3.3,1 \mathrm{H}), 3.34-3.32$ $(\mathrm{dt}, J=6.1,3.1,1 \mathrm{H}), 3.30(\mathrm{~m}, 1 \mathrm{H}), 3.00(\mathrm{~m}, 1 \mathrm{H}), 2.61(\mathrm{~m}, 1 \mathrm{H}) ;{ }^{13} \mathrm{C}$ NMR $\left(125 \mathrm{MHz}, \mathrm{CDCl}_{3}\right) \square 139.4,139.2$, 139.9, 136.0, 128.8, 128.7, 128.6, 128.5, 128.3, 127.92, 127.87, 127.81, 127.78, 117.3, 79.1, 78.6, 75.6, 73.6, 73.5, 72.2, 72.0, 34.9; IR (thin film) 3029, 2866, 1453, 1358, 1108, $1066 \mathrm{~cm}^{-1}$; HRMS (EI/GCMS) $\mathrm{m} / \mathrm{z}$ calcd for $\mathrm{C}_{29} \mathrm{H}_{32} \mathrm{NaO}_{4}(\mathrm{M}+\mathrm{Na})^{+} 467.2198$, found 467.2187 .

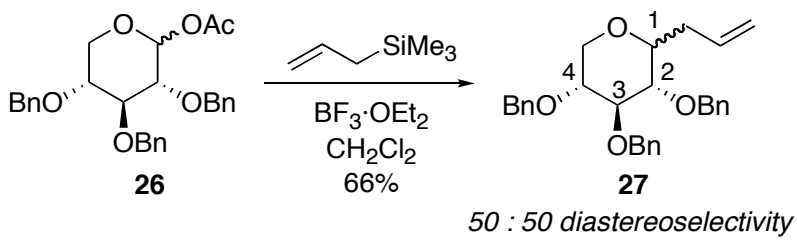

1-Allyl-2,3,4-tri- $\boldsymbol{O}$-benzylxylopyranose (27): Under standard allylation conditions using $\mathrm{BF}_{3} \cdot \mathrm{OEt}_{2}$ as a Lewis acid, acetate $26(0.158 \mathrm{~g}, 0.342 \mathrm{mmol})$ afforded $27(0.100 \mathrm{~g}, 66 \%)$ as a 1:1 1,4-trans:cis mixture of isomer.

Careful flash chromatography (hexanes to 1:9 $\mathrm{Et}_{2} \mathrm{O} /$ hexanes) provided a clean sample of the 1,4-trans product: ${ }^{1} \mathrm{H}$ NMR $\left(500 \mathrm{MHz}, \mathrm{CDCl}_{3}\right) \square 7.35-7.25(\mathrm{~m}, 15 \mathrm{H}), 5.80(\mathrm{~m}, 1 \mathrm{H}), 5.10(\mathrm{~m}, 2 \mathrm{H}), 4.97(\mathrm{~d}, J=11.0,1 \mathrm{H}), 4.90(\mathrm{~d}$, $J=10.8,1 \mathrm{H}), 4.83(\mathrm{~d}, J=11.0,1 \mathrm{H}), 4.71(\mathrm{~d}, J=11.6,1 \mathrm{H}), 4.63-4.61(\mathrm{~d}, J=11.7,1 \mathrm{H}$ and $\mathrm{d}, J=10.8,1 \mathrm{H})$, $3.99(\mathrm{dd}, J=11.0,5.0,1 \mathrm{H}), 3.65-3.57(\mathrm{~m}, 2 \mathrm{H}), 3.30-3.23(\mathrm{~m}, 2 \mathrm{H}), 3.16(\mathrm{t}, J=10.8,1 \mathrm{H}), 2.61(\mathrm{~m}, 1 \mathrm{H}), 2.20$ (m, 1H); ${ }^{1} \mathrm{H}$ NMR (500 MHz, $\left.\mathrm{C}_{6} \mathrm{D}_{6}\right) \square 7.36-7.01(\mathrm{~m}, 15 \mathrm{H}), 6.08-6.00(\mathrm{~m}, 1 \mathrm{H}), 5.12(\mathrm{~m}, 2 \mathrm{H}), 5.00(\mathrm{~d}, J=11.4$, $1 \mathrm{H}), 4.93(\mathrm{~d}, J=11.3,1 \mathrm{H}), 4.82(\mathrm{~d}, J=11.3,1 \mathrm{H}), 4.54(\mathrm{~d}, J=11.4,1 \mathrm{H}), 4.42(\mathrm{~d}, J=11.9,1 \mathrm{H}), 4.34(\mathrm{~d}, J=$ $11.9,1 \mathrm{H}), 3.94-3.90(\mathrm{dd}, J=11.0,5.0,1 \mathrm{H}), 3.62-3.59(\mathrm{t}, J=9.0,1 \mathrm{H}), 3.57-3.51$ (ddd, $J=10.3,9.1,5.2,1 \mathrm{H})$, $3.25(\mathrm{~m}, 2 \mathrm{H}), 3.08-3.03(\mathrm{t}, J=11.0,1 \mathrm{H}), 2.65-2.61(\mathrm{~m}, 1 \mathrm{H}), 2.33-2.30(\mathrm{~m}, 1 \mathrm{H}) ;{ }^{13} \mathrm{C} \mathrm{NMR}\left(125 \mathrm{MHz}, \mathrm{CDCl}_{3}\right)$ $\square$ 139.2, 138.73, 138.69, 135.1, 129.0, 128.93, 128.90, 128.40, 128.37, 128.32, 128.26, 128.1, 117.7, 86.9, 81.7, 
79.7, 79.3, 76.0, 75.7, 73.7, 68.5, 36.7; IR (thin film) 3064, 3030, 2909, 2863, 1496, 1454, $1102 \mathrm{~cm}^{-1}$; HRMS (EI/GCMS) $m / z$ calcd for $\mathrm{C}_{29} \mathrm{H}_{32} \mathrm{NaO}_{4}(\mathrm{M}+\mathrm{Na})^{+} 467.2198$, found 467.2186.

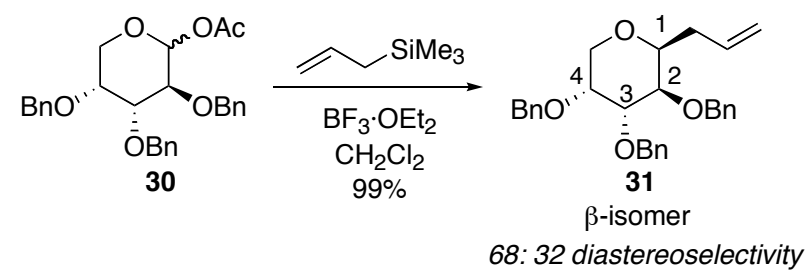

1-Allyl-2,3,4-tri- $\boldsymbol{O}$-benzylarabinopyranose (31): Under standard allylation conditions using $\mathrm{BF}_{3} \cdot \mathrm{OEt}_{2}$ as a Lewis acid, acetate $\mathbf{3 0}(0.479 \mathrm{~g}, 1.04 \mathrm{mmol})$ afforded $\mathbf{3 1}(0.454 \mathrm{~g}, 99 \%)$ as a 68:32 1,4-trans:cis mixture of isomers. The isomers were resolved by careful flash chromatography (hexanes to $1: 9 \mathrm{Et}_{2} \mathrm{O} /$ hexanes) to allow for individual characterization:

1,4-trans isomer (31】): ${ }^{1} \mathrm{H}$ NMR (500 MHz, $\left.\mathrm{CDCl}_{3}\right) \square 7.35-7.18(\mathrm{~m}, 15 \mathrm{H}), 5.73-5.65(\mathrm{~m}, 1 \mathrm{H}), 5.01(\mathrm{~m}, 2 \mathrm{H})$, $4.74(\mathrm{~m}, 1 \mathrm{H}), 4.52(\mathrm{~m}, 3 \mathrm{H}), 4.40(\mathrm{~m}, 2 \mathrm{H}), 3.86(\mathrm{~m}, 3 \mathrm{H}), 3.71(\mathrm{~m}, 2 \mathrm{H}), 3.33(\mathrm{~m}, 1 \mathrm{H}), 2.41-2.36(\mathrm{~m}, 1 \mathrm{H})$, 2.20-2.14 (m, 1H); ${ }^{1} \mathrm{H}$ NMR $\left(500 \mathrm{MHz}, \mathrm{C}_{6} \mathrm{D}_{6}\right) \square 7.34-7.07(\mathrm{~m}, 15 \mathrm{H}), 5.84(\mathrm{~m}, 1 \mathrm{H}), 5.06(\mathrm{~m}, 2 \mathrm{H}), 4.80(\mathrm{~d}, J=$ $12.1,1 \mathrm{H}), 4.55(\mathrm{~d}, J=12.1,1 \mathrm{H}), 4.30-4.18(\mathrm{~m}, 4 \mathrm{H}), 4.01-3.93(\mathrm{~m}, 5 \mathrm{H}), 3.40-3.39(\mathrm{dd}, J=3.9,1.6,1 \mathrm{H})$, 2.69-2.64 (m, 1H), 2.41-2.37 (m, 1H); ${ }^{13} \mathrm{C}$ NMR (125 MHz, $\left.\mathrm{CDCl}_{3}\right) \square 138.9,138.7,138.2,135.2,128.7,128.6$, $128.5,128.2,128.1,128.0,127.93,127.90,117.2,76.5,74.3,73.3,73.2,73.0,72.7,71.7,64.8,35.4$; IR (thin film) 3030, 2868, 1454, $1096 \mathrm{~cm}^{-1}$; HRMS (EI/GCMS) $\mathrm{m} / \mathrm{z}$ calcd for $\mathrm{C}_{29} \mathrm{H}_{32} \mathrm{NaO}_{4}(\mathrm{M}+\mathrm{Na})^{+} 467.2198$, found 467.2213.

1,4-cis-isomer (31]): ${ }^{1} \mathrm{H}$ NMR (500 MHz, $\left.\mathrm{CDCl}_{3}\right) \square 7.41-7.18(\mathrm{~m}, 15 \mathrm{H}), 5.94-5.89(\mathrm{~m}, 1 \mathrm{H}), 5.09(\mathrm{~m}, 2 \mathrm{H})$, $4.89(\mathrm{~d}, J=10.8,1 \mathrm{H}), 4.80(\mathrm{~d}, J=12.7,1 \mathrm{H}), 4.73-4.62(\mathrm{~m}, 3 \mathrm{H}), 4.55(\mathrm{~d}, J=12.0,1 \mathrm{H}), 4.09$ (dd, $J=12.8,2.1$, $1 \mathrm{H}), 3.75(\mathrm{~m}, 1 \mathrm{H}), 3.72(\mathrm{t}, J=9.2,1 \mathrm{H}), 3.56-3.54(\mathrm{dd}, J=9.2,3.2,1 \mathrm{H}), 3.26-3.23(\mathrm{~m}, 2 \mathrm{H}), 2.63(\mathrm{~m}, 1 \mathrm{H}), 2.35$ $(\mathrm{m}, 1 \mathrm{H}) ;{ }^{1} \mathrm{H}$ NMR $\left(500 \mathrm{MHz}, \mathrm{C}_{6} \mathrm{D}_{6}\right) \square 7.37-7.07(\mathrm{~m}, 15 \mathrm{H}), 6.15(\mathrm{~m}, 1 \mathrm{H}), 5.14(\mathrm{~m}, 2 \mathrm{H}), 5.02(\mathrm{~d}, J=11.3,1 \mathrm{H})$, $4.55(\mathrm{~m}, 2 \mathrm{H}), 4.40-4.20(\mathrm{~m}, 3 \mathrm{H}), 3.90(\mathrm{~m}, 2 \mathrm{H}), 3.34(\mathrm{~m}, 2 \mathrm{H}), 3.27-3.23(\mathrm{ddd}, J=9.1,7.8,3.1,1 \mathrm{H}), 2.83(\mathrm{~d}, J=$ 12.3, 1H), 2.71-2.69 (m, 1H), 2.47-2.44 (m, 1H); $\left.{ }^{13} \mathrm{C} \mathrm{NMR} \mathrm{(125} \mathrm{MHz,} \mathrm{CDCl}_{3}\right) \square 138.8,138.6,135.4,128.63$, 128.61, 128.6, 128.4, 128.2, 128.04, 127.92, 127.89, 127.86, 117.1, 83.2, 79.9, 78.6, 75.6, 72.7, 71.7, 71.3, 67.1, $36.5 ;{ }^{13} \mathrm{C}$ NMR $\left(125 \mathrm{MHz}, \mathrm{C}_{6} \mathrm{D}_{6}\right) \square 139.3,139.1,138.7,135.7,128.5,128.44,128.39,127.7,127.62,127.60$, 127.5, 116.6, 77.6, 74.6, 74.2, 73.4, 73.3, 72.7, 71.3, 64.4, 35.6; IR (thin film) 2907, 2862, 1453, $1093 \mathrm{~cm}^{-1}$; HRMS (EI/GCMS) $m / z$ calcd for $\mathrm{C}_{29} \mathrm{H}_{32} \mathrm{O}_{4}(\mathrm{M}+\mathrm{Na})^{+} 467.2198$, found 467.2199.

\section{Stereochemical proofs of nucleophilic substituted products}

A. Tetrahydropyran 10

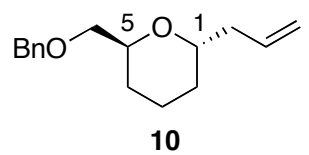

The determination of the relative stereochemistry of tetrahydropyran $\mathbf{1 0}$ was achieved through nOe spectroscopy. Because the 1,5-trans product is symmetric, it consists of two conformers, 10a and 10b, where the equilibrium constant is approximately one.

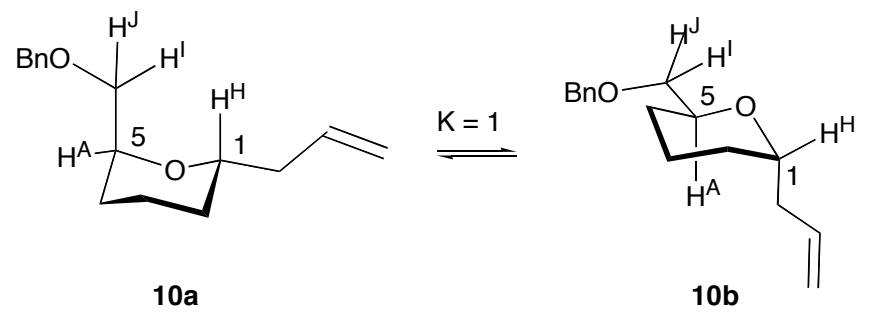


The small coupling constants $(6.4 \mathrm{~Hz}$ and $3.8 \mathrm{~Hz})$ observed for $\mathrm{H}^{\mathrm{H}}$ suggested that the allyl group at $\mathrm{C}-1$ was in the axial position although the stereochemistry at C-5 could not be determined from coupling constant data. The 1,5-trans stereochemistry was assigned based on the observed enhancements of $\mathrm{H}^{\mathrm{I}}, \mathrm{H}^{\mathrm{J}}, \mathrm{H}^{\mathrm{K}}$, and $\mathrm{H}^{\mathrm{L}}$ when $\mathrm{H}^{\mathrm{A}}$ was irradiated but no enhancement of $\mathrm{H}^{\mathrm{H}}$ was observed. In addition, the nOe enhancements of $\mathrm{H}^{\mathrm{I}}, \mathrm{H}^{\mathrm{J}}, \mathrm{H}^{\mathrm{K}}$, and $\mathrm{H}^{\mathrm{L}}$ when $\mathrm{H}^{\mathrm{H}}$ was irradiated further confirmed the presence of both 1,5-trans conformers.
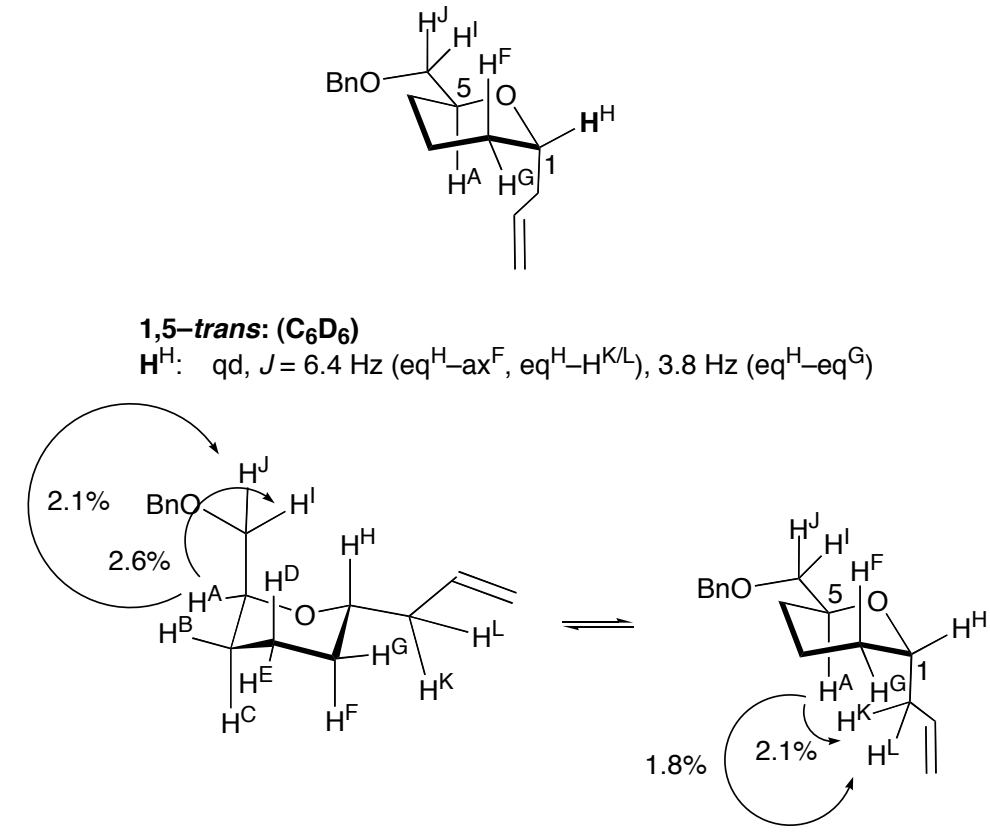

1,5-trans: $\left(\mathrm{CDCl}_{3}\right)$

(Mixing time was $2 \mathrm{~s}$ )

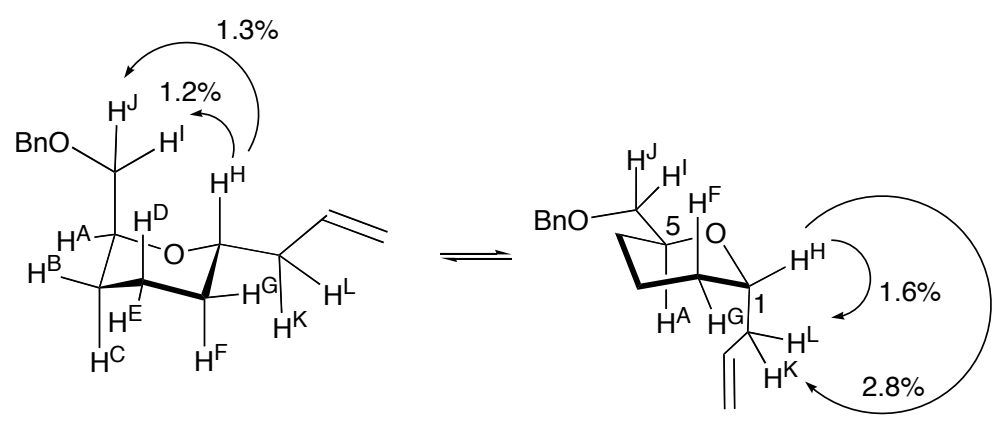

1,5-trans: $\left(\mathrm{CDCl}_{3}\right)$

(Mixing time was $2 \mathrm{~s}$ ) 


\section{B. Tetrahydropyran 14}

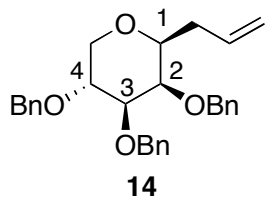

The stereochemistry for tetrahydropyran 14 was assigned based on key coupling constants and nOe analysis. The large $(12.6 \mathrm{~Hz})$ coupling constant observed between $\mathrm{H}^{\mathrm{A}}$ and $\mathrm{H}^{\mathrm{C}}$ suggests that both $\mathrm{H}^{\mathrm{A}}$ and $\mathrm{H}^{\mathrm{C}}$ are oriented axially. The coupling constants that exist for $\mathrm{H}^{\mathrm{D}}$ allow for the determination of the stereochemistry at C-2, C-3, and C-4. Finally, to corroborate the proposed stereochemical relationship between the protons, nOe measurements were taken. Irradiation of $\mathrm{H}^{\mathrm{A}}$ resulted in the enhancements of $\mathrm{H}^{\mathrm{D}}$ and $\mathrm{H}^{\mathrm{F}}$. In addition, the irradiation of $\mathrm{H}^{\mathrm{F}}$ resulted in the enhancements of $\mathrm{H}^{\mathrm{A}}$ and $\mathrm{H}^{\mathrm{D}}$.

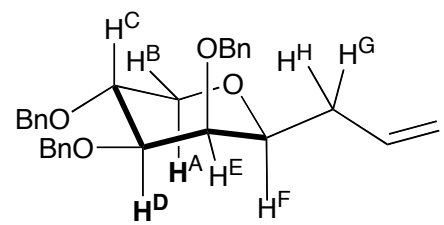

$$
\begin{aligned}
& \text { 1,4-trans } \\
& \mathrm{H}^{\mathrm{A}}: \mathrm{t}, J=12.6 \mathrm{~Hz}\left(\mathrm{gem}, \mathrm{ax}^{\mathrm{A}}-\mathrm{ax}^{\mathrm{C}}\right) \\
& \mathrm{H}^{\mathrm{D}}: \mathrm{dd}, J=8.8 \mathrm{~Hz}\left(\mathrm{ax}^{\mathrm{D}}-\mathrm{ax}^{\mathrm{C}}\right), 2.8 \mathrm{~Hz}\left(\mathrm{ax}^{\mathrm{D}}-\mathrm{eq}^{\mathrm{E}}\right)
\end{aligned}
$$
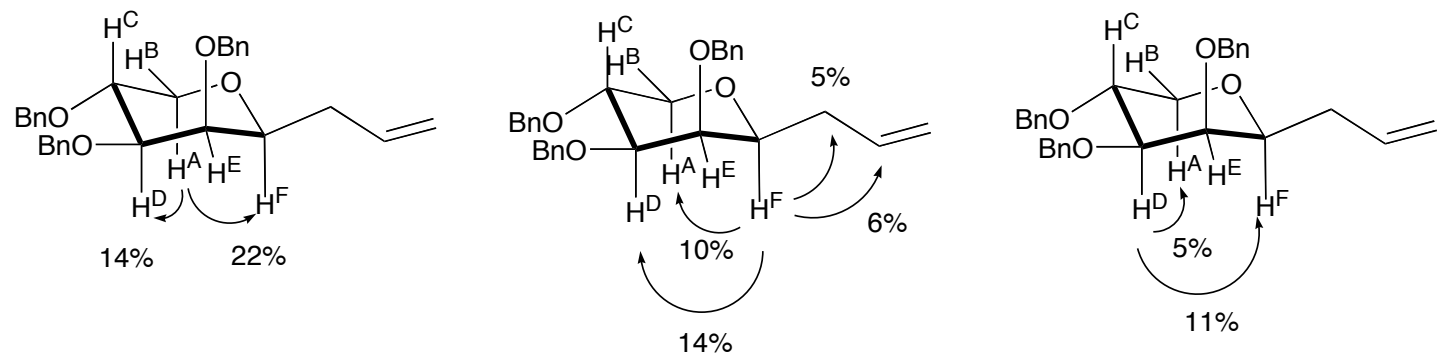

C. Tetrahydropyran $\mathbf{2 3}$

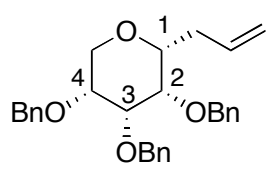

23

Assigning the stereochemistry for product $\mathbf{2 3}$ relied only on coupling constant data. The 1,3-diaxial interaction between the C-2 and C-4 benzyloxy substituents exists in one of two possible conformations of the $\square$-product. The other conformer has the C-2 and C-4 benzyloxy groups in their equatorial positions but there is a 1,3diaxial interaction $(2.4 \mathrm{kcal} / \mathrm{mol})^{10}$ between the $\mathrm{C}-1$ allyl and $\mathrm{C}-3$ benzyloxy groups. The 1,3-diaxial interaction between the $\mathrm{C}-2$ and $\mathrm{C}-4$ alkoxy groups $(1.9 \mathrm{kcal} / \mathrm{mol})^{10}$ is not as severe as the 1,3 -diaxial interaction between the $\mathrm{C}-1$ allyl and C-4 alkoxy groups. As a result, the $\square$-product primarily exists with the C-2 and C-4 alkoxy groups in the axial positions and the allyl group in the equatorial position. Because many of the peaks in the ${ }^{1} \mathrm{H}$ NMR spectrum overlapped when $\mathrm{CDCl}_{3}$ was employed as the solvent, an alternative solvent, $\mathrm{C}_{6} \mathrm{D}_{6}$, was necessary to allow for resolution of peaks. In both deuterated solvents, $\mathrm{H}^{\mathrm{A}}$ was assigned both large $(\sim 12.0 \mathrm{~Hz})$ and small $(4.5-6.2 \mathrm{~Hz})$ coupling constants. The results indicated that $\mathrm{H}^{\mathrm{C}}$ is in the equatorial position. The stereochemistry at C-4 is further confirmed by the coupling constants observed for both $\mathrm{H}^{\mathrm{C}}$ and $\mathrm{H}^{\mathrm{D}}$. The allyl 
group is reasoned to be in the equatorial position because the A-value for a C-2 alkyl group on a tetrahydropyran ring $(2.8 \mathrm{kcal} / \mathrm{mol})$ suggests that the substituent does not favor an axial position. ${ }^{11}$

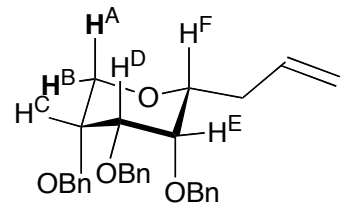

$\square$-product: $\left(\mathrm{CDCl}_{3}\right)$

$\mathrm{H}^{\mathrm{A}}$ : $\quad \mathrm{dd}, J=12.1 \mathrm{~Hz}(\mathrm{gem}), 4.5 \mathrm{~Hz}\left(\mathrm{ax}^{\mathrm{A}}-\mathrm{ax}^{\mathrm{C}}\right)$

$\mathbf{H}^{\mathrm{B}}: \quad \mathrm{dd}, J=12.1 \mathrm{~Hz}(\mathrm{gem}), 2.6 \mathrm{~Hz}\left(\mathrm{eq}^{\mathrm{B}}-\mathrm{ax}^{\mathrm{C}}\right)$

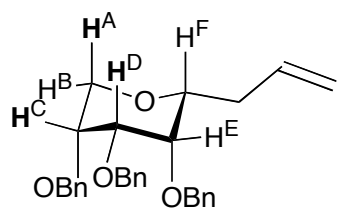

D-product: $\left(\mathrm{C}_{6} \mathrm{D}_{6}\right)$ :

$\mathrm{H}^{\mathrm{A}}: \quad \mathrm{dd}, J=11.6 \mathrm{~Hz}(\mathrm{gem}), 6.2 \mathrm{~Hz}\left(\mathrm{ax}^{\mathrm{A}}-\mathrm{ax}^{\mathrm{C}}\right)$

$H^{C}: \quad d t, J=6.1 \mathrm{~Hz}\left(e q^{\mathrm{C}}-a x^{\mathrm{A}}\right), 3.1 \mathrm{~Hz}\left(\mathrm{eq}^{\mathrm{C}}-\mathrm{eq}^{\mathrm{B}}, \mathrm{eq}^{\mathrm{C}}-\mathrm{ax}^{\mathrm{D}}\right)$

$H^{\mathrm{D}}: \quad \mathrm{t}, J=3.3 \mathrm{~Hz}\left(\mathrm{ax}^{\mathrm{D}}-\mathrm{eq}^{\mathrm{C}}, \mathrm{ax}^{\mathrm{D}}-\mathrm{eq}^{\mathrm{E}}\right)$

D. Tetrahydropyran 27<smiles>C=CC[C@H]1OC[C@@H](OBr)[C@H](O)[C@@H]1OCc1ccccc1</smiles>

27马

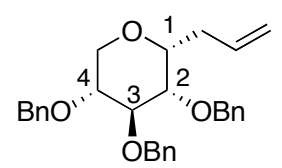

27马

The relative stereochemical relationships of the protons on tetrahydropyran 27 $\square$ were determined by coupling constant data. For example, the large coupling constants $(11.0 \mathrm{~Hz})$ for $\mathrm{H}^{\mathrm{A}}$ suggests that this proton and $\mathrm{H}^{\mathrm{C}}$ are both axial. In addition, the large coupling constants $(9.0 \mathrm{~Hz})$ between $\mathrm{H}^{\mathrm{D}}$ and both $\mathrm{H}^{\mathrm{C}}$ and $\mathrm{H}^{\mathrm{E}}$ indicate that $\mathrm{H}^{\mathrm{C}}$, $\mathrm{H}^{\mathrm{D}}$, and $\mathrm{H}^{\mathrm{E}}$ are axial. The stereochemical assignment was confirmed by DPFSG-NOE measurements.

Irradiation of $\mathrm{H}^{\mathrm{A}}$ enhanced $\mathrm{H}^{\mathrm{D}}$ and $\mathrm{H}^{\mathrm{F}}$, suggesting that these three protons occupied axial positions and the allyl group was in the equatorial position

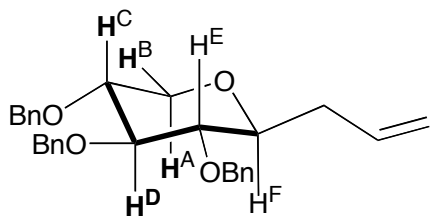

$27 \square$

$$
\begin{aligned}
& \mathbf{H}^{\mathrm{A}}: \mathrm{t}, J=11.0 \mathrm{~Hz}\left(\mathrm{gem}, \mathrm{ax}^{\mathrm{A}}-\mathrm{ax}^{\mathrm{C}}\right) \\
& \mathbf{H}^{\mathrm{B}}: \mathrm{dd}, J=11.0 \mathrm{~Hz}(\mathrm{gem}), 5.0 \mathrm{~Hz}\left(\mathrm{eq}^{\mathrm{B}}-\mathrm{ax}{ }^{\mathrm{C}}\right) \\
& \mathrm{H}^{\mathrm{C}} \text { : ddd, } J=10.3 \mathrm{~Hz}\left(\mathrm{ax}^{\mathrm{C}}-\mathrm{ax}^{\mathrm{A}}\right), 9.1 \mathrm{~Hz}\left(\mathrm{ax} \mathrm{C}^{\mathrm{C}}-\mathrm{ax}^{\mathrm{D}}\right), 5.2 \mathrm{~Hz}\left(\mathrm{ax}^{\mathrm{C}}-\mathrm{eq}^{\mathrm{B}}\right) \\
& H^{\mathrm{D}}: \mathrm{t}, J=9.0 \mathrm{~Hz}\left(\mathrm{ax}^{\mathrm{D}}-\mathrm{ax}{ }^{\mathrm{C} / \mathrm{E}}\right)
\end{aligned}
$$

E. Tetrahydropyran $\mathbf{3 1}$

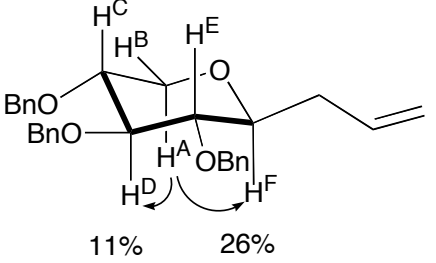

(Mixing time was $2 \mathrm{~s}$ )

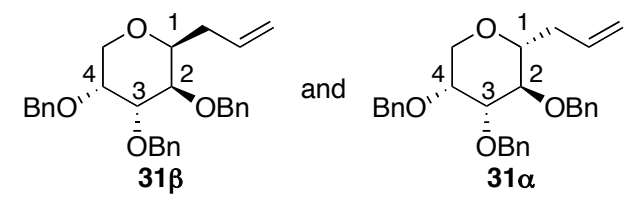

Because the allylation to form alkene $\mathbf{3 1}$ proved to be unselective, the isomers were separated and analyzed. Assigning the relative stereochemistry of the major product $31 \square$ was not possible because the peaks in the ${ }^{1} \mathrm{H}$ NMR spectrum overlapped when $\mathrm{CDCl}_{3}$ or $\mathrm{C}_{6} \mathrm{D}_{6}$ were employed as solvents. Alternatively, focus turned towards determining the stereochemistry of the minor product, 31 $\mathrm{\square}$, by ${ }^{1} \mathrm{H}$ NMR spectroscopy and nOe spectroscopy in both $\mathrm{CDCl}_{3}$ and $\mathrm{C}_{6} \mathrm{D}_{6}$ solvents. In $\mathrm{CDCl}_{3}$, a $9.2 \mathrm{~Hz}$ coupling constant was observed between $\mathrm{H}^{\mathrm{D}}$ and $\mathrm{H}^{\mathrm{E}}$, suggesting that both protons are axial. In addition, the small coupling constant between $\mathrm{H}^{\mathrm{D}}$ and $\mathrm{H}^{\mathrm{C}}$ indicated that $\mathrm{H}^{\mathrm{C}}$ was in the equatorial position. The large $(9.2 \mathrm{~Hz})$ coupling constants between $\mathrm{H}^{\mathrm{E}}$ and both $\mathrm{H}^{\mathrm{D}}$ 
and $\mathrm{H}^{\mathrm{F}}$ suggest that all three protons are axial. The nOe enhancements observed for $\mathbf{3 1} \square$ are in complete agreement with the coupling constant data. Since nOe measurements from $\mathrm{H}^{\mathrm{A}}$ to $\mathrm{H}^{\mathrm{D}}$ and $\mathrm{H}^{\mathrm{F}}$ were large, the structure of $31[$ was assigned as shown.

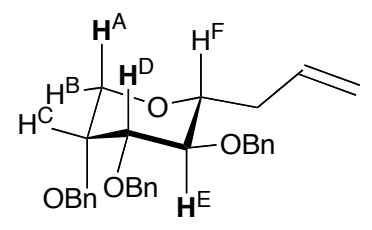

31]: $\left(\mathrm{CDCl}_{3}\right)$

$\mathrm{H}^{\mathrm{A}}: \quad \mathrm{dd}, J=12.8 \mathrm{~Hz}(\mathrm{gem}), 2.1 \mathrm{~Hz}\left(\mathrm{ax}^{\mathrm{A}}-\mathrm{eq}^{\mathrm{C}}\right)$

$H^{\mathrm{D}}: \quad \mathrm{dd}, J=9.2 \mathrm{~Hz}\left(\mathrm{ax}^{\mathrm{D}}-\mathrm{ax} \mathrm{E}^{\mathrm{E}}\right), 3.3 \mathrm{~Hz}\left(\mathrm{ax}^{\mathrm{D}}-\mathrm{eq}^{\mathrm{C}}\right)$

$H^{\mathrm{E}}: \quad \mathrm{t}, J=9.2\left(\mathrm{ax}^{\mathrm{E}}-\mathrm{ax}^{\mathrm{D}}, \mathrm{ax} \mathrm{E}-\mathrm{ax} \mathrm{F}^{\mathrm{F}}\right)$

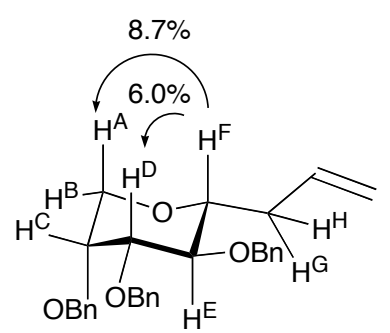

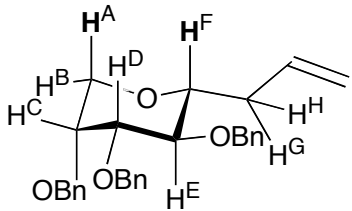

31口: $\left(\mathrm{C}_{6} \mathrm{D}_{6}\right)$

$H^{A}: \quad d, J=12.3 \mathrm{~Hz}(\mathrm{gem})$

$\mathbf{H}^{\mathrm{F}}: \quad \mathrm{ddd}, J=9.1 \mathrm{~Hz}\left(\mathrm{ax}^{\mathrm{F}}-\mathrm{ax} \mathrm{E}\right), 7.8 \mathrm{~Hz}\left(\mathrm{ax}^{\mathrm{F}}-\mathrm{vicinal}^{\mathrm{G}}\right), 3.1\left(\mathrm{ax}^{\mathrm{F}}-\right.$ vicinal $\left.^{\mathrm{H}}\right)$

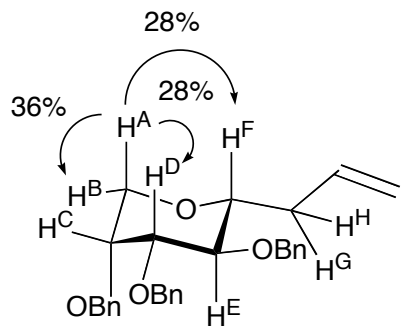

31口: $\left(\mathrm{C}_{6} \mathrm{D}_{6}\right)$

(Mixing time was $2 \mathrm{~s}$ )

\section{Bibliography}

(1) Pangborn, A. B.; Giardello, M. A.; Grubbs, R. H.; Rosen, R. K.; Timmers, F. J. Organometallics 1996, $15,1518-1520$.

(2) Marco-Contelles, J.; Gallego, P.; Rodríguez-Fernández, M.; Khiar, N.; Destabel, C.; Bernabé, M.;

Martínez-Grau, A.; Chiara, J. L. J. Org. Chem. 1997, 62, 7397-7412.

(3) Barua, N. C.; Schmidt, R. R. Synthesis 1986, 1067-1070.

(4) Dounay, A. B.; Urbanek, R. A.; Frydrychowski, V. A.; Forsyth, C. J. J. Org. Chem. 2001, 66, 925-938.

(5) Dahanukar, V. H.; Rychnovsky, S. D. J. Org. Chem. 1996, 61, 8317-8320.

(6) Dhawan, S. N.; Chick, T. L.; Goux, W. J. Carbohydr. Res. 1988, 172, 297-307.

(7) Jackson, E. L.; Hudson, C. S. J. Am. Chem. Soc. 1941, 63, 1229-1231.

(8) Tsuda, Y.; Nunozawa, T.; Yoshimoto, K. Chem. Pharm. Bull. 1980, 28, 3223-3231.

(9) Pouchert, C. J.; Behnke, J. In The Aldrich Library of ${ }^{13} \mathrm{C}$ and ${ }^{1} H$ FT NMR Spectra; Aldrich: Milwaukee, 1993; Vol. 1, p 302.

(10) Rablen, P. R.; Paquette, L. A.; Borden, W. T. J. Org. Chem. 2000, 65, 9180-9185.

(11) Eliel, E. L.; Hargrave, K. D.; Pietrusiewicz, K. M.; Manoharan, M. J. Am. Chem. Soc. 1982, 104, 36353643. 
V. Selected GCMS and ${ }^{1} \mathrm{H}$ NMR spectra
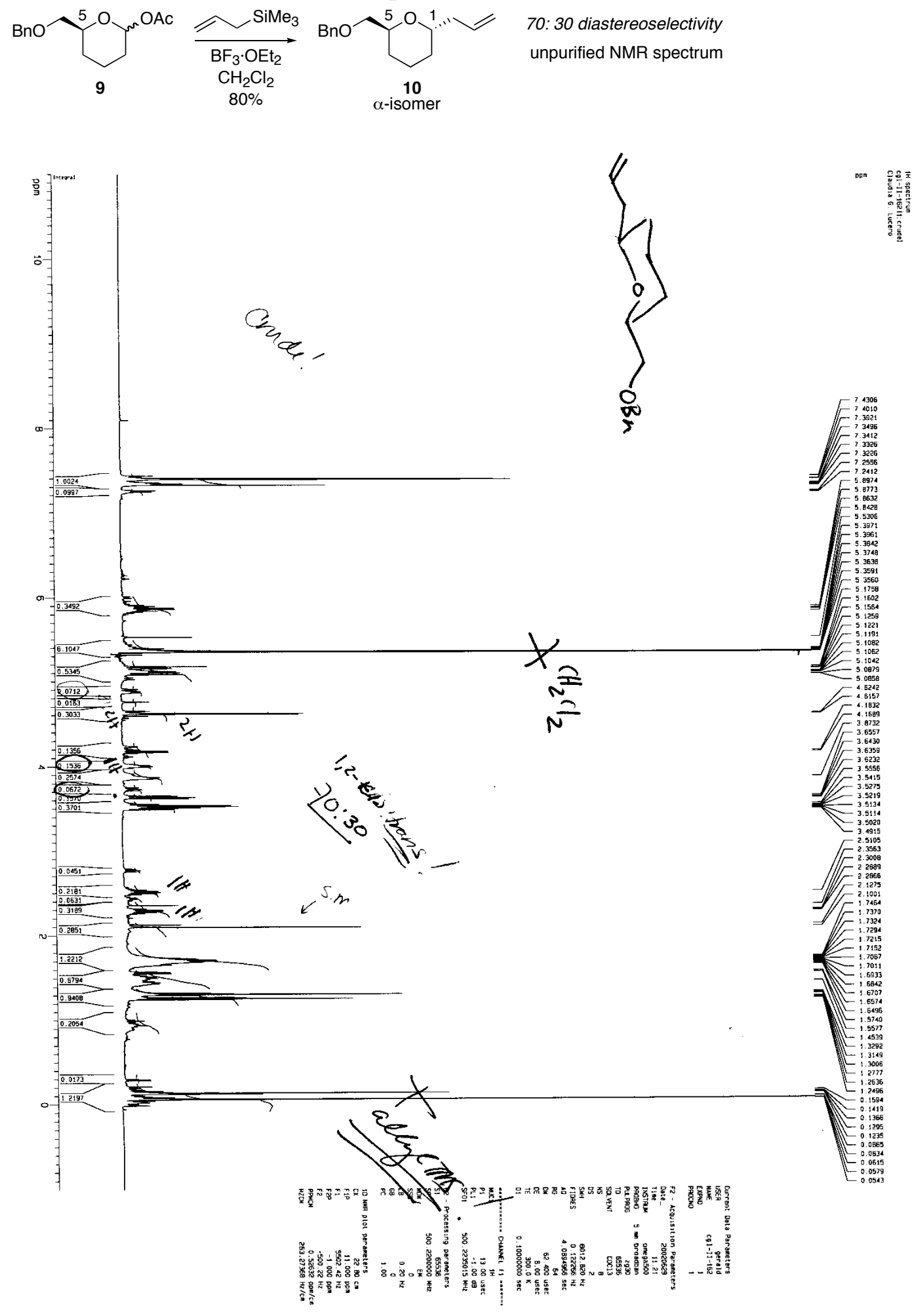

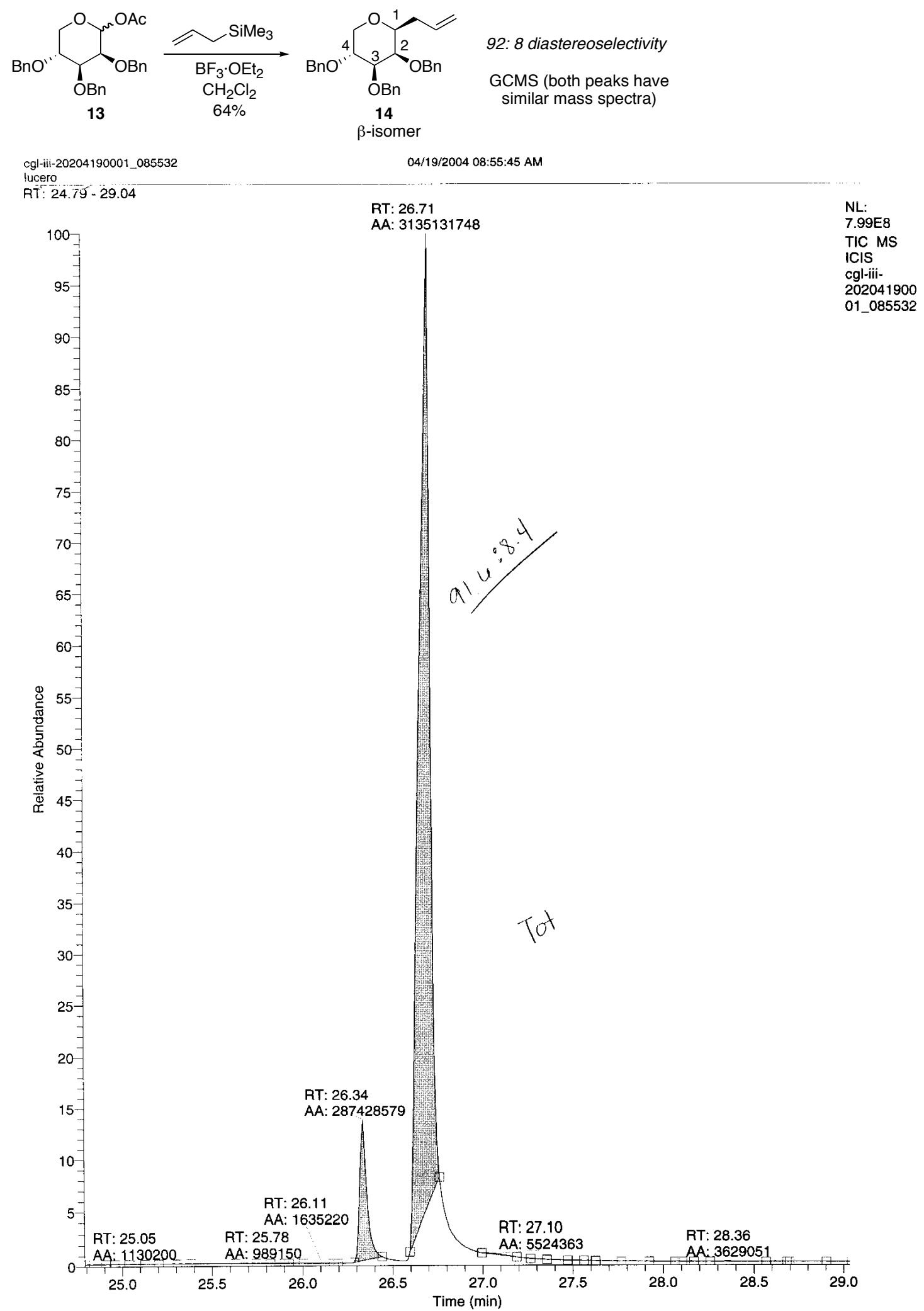

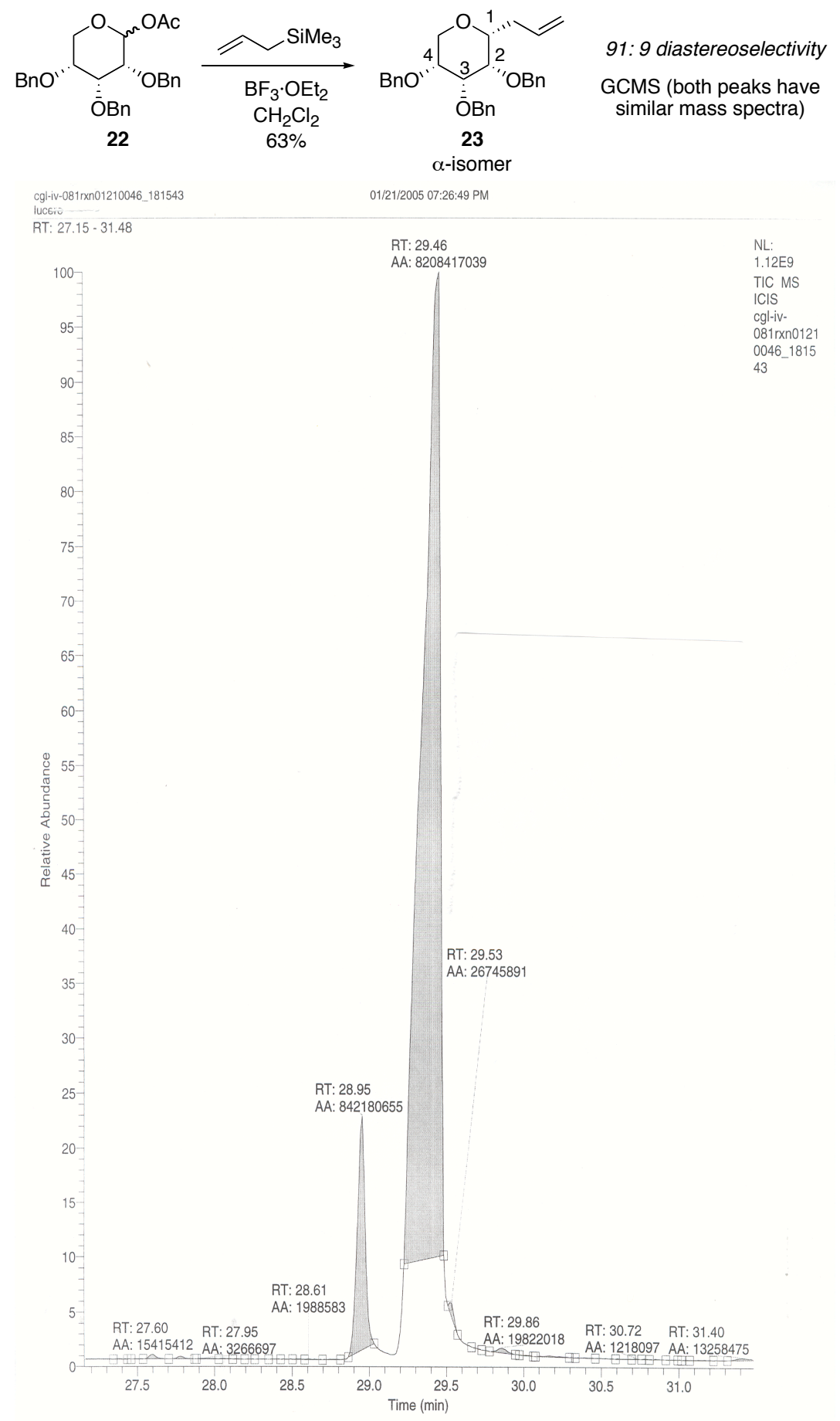


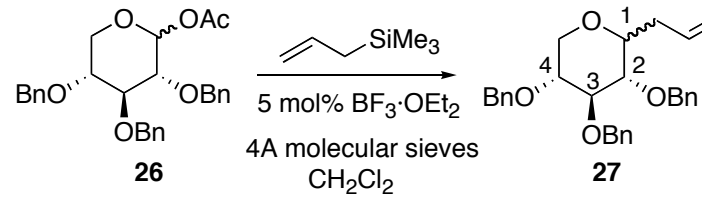

IIGcms2\F....lcgl-shuto-205170022_215412

lucero

RT: $: 28-27.84$$$
\begin{aligned}
& 100 \\
& 95 \\
& 90 \\
& 85
\end{aligned}
$$

75

70

65

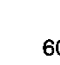

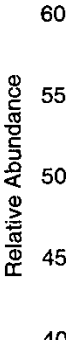

40

$$
35
$$

$$
30
$$

\section{-}

05/17/2005 09:54:25 PM
$79: 21$ diastereoselectivity
GCMS (both peaks have similar mass spectra)

Note that this experiment reflects the use of Shuto's conditions ( Tamura, S.; Abe, H.; Matsuda, A.; Shuto,

S. Angew. Chem. Int. Ed. 2003, 42, 1021-1023). Under our conditions, a 50:50 mixture of products was formed.

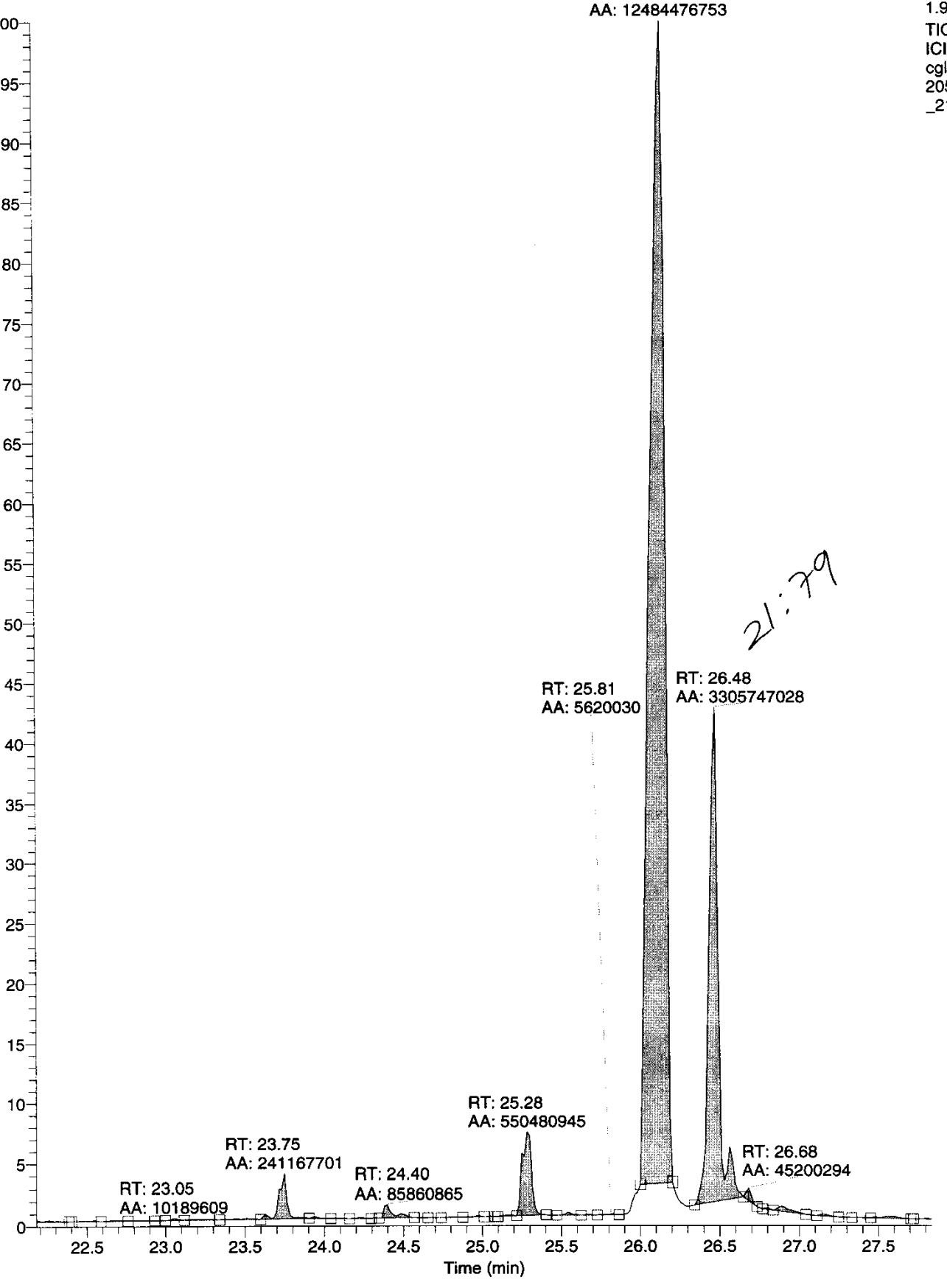

NL:

99E9

TIC MS

CIS

05170022

-215412 

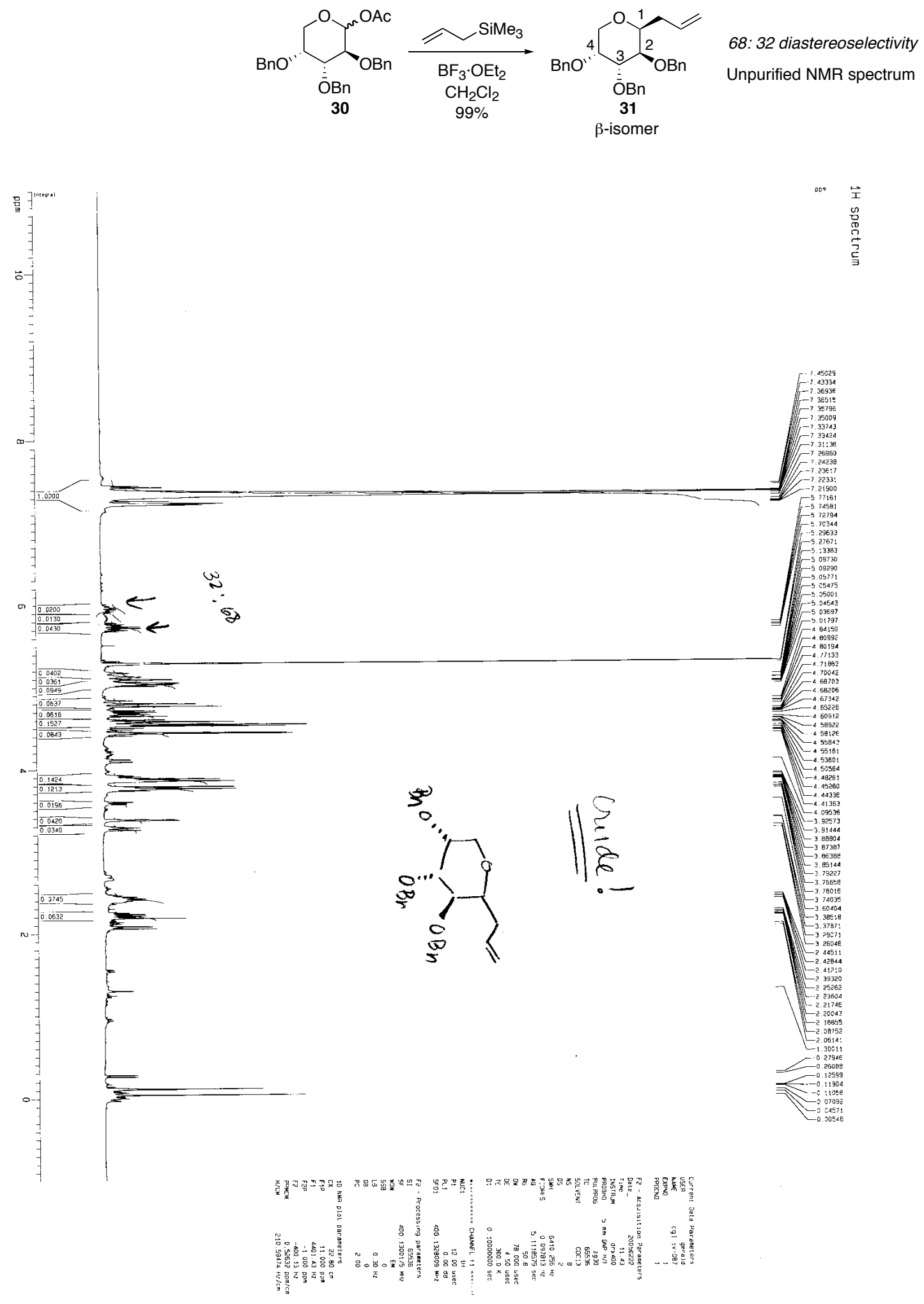